Article

\title{
Impact of Metallic Nanoparticles on In Vitro Culture, Phenolic Profile and Biological Activity of Two Mediterranean Lamiaceae Species: Lavandula viridis L'Hér and Thymus lotocephalus G. López and R. Morales
}

\author{
Sandra Gonçalves ${ }^{1, *}+\mathbb{D}^{\mathbb{D}}$, Inês Mansinhos ${ }^{1,+} \mathbb{D}$, Raquel Rodríguez-Solana ${ }^{1,2}$, Gema Pereira-Caro ${ }^{2} \mathbb{D}$, \\ José Manuel Moreno-Rojas ${ }^{2}$ (D) and Anabela Romano ${ }^{1, *(\mathbb{D})}$ \\ 1 MED-Mediterranean Institute for Agriculture, Environment and Development, Faculdade de Ciências e \\ Tecnologia, Universidade do Algarve, Campus de Gambelas, 8005-139 Faro, Portugal; \\ ifmansinhos@ualg.pt (I.M.); rrsolana@ualg.pt or raquel.rodriguez.solana@juntadeandalucia.es (R.R.-S.) \\ 2 Department of Food Science and Health, Andalusian Institute of Agricultural and Fisheries Research and \\ Training (IFAPA), Avenida Menendez-Pidal, SN, 14004 Córdoba, Spain; \\ mariag.pereira@juntadeandalucia.es (G.P.-C.); josem.moreno.rojas@juntadeandalucia.es (J.M.M.-R.) \\ * Correspondence: smgoncalves@ualg.pt (S.G.); aromano@ualg.pt (A.R.); Tel.: +351-289800910 (A.R.) \\ + These authors contributed equally to this work.
}

check for updates

Citation: Gonçalves, S.; Mansinhos, I.; Rodríguez-Solana, R.; Pereira-Caro, G.; Moreno-Rojas, J.M.; Romano, A. Impact of Metallic Nanoparticles on In Vitro Culture, Phenolic Profile and Biological Activity of Two

Mediterranean Lamiaceae Species: Lavandula viridis L'Hér and Thymus lotocephalus G. López and R. Morales. Molecules 2021, 26, 6427. https:// doi.org/10.3390/molecules26216427

Academic Editor: Petras Rimantas Venskutonis

Received: 11 August 2021

Accepted: 21 October 2021

Published: 25 October 2021

Publisher's Note: MDPI stays neutral with regard to jurisdictional claims in published maps and institutional affiliations.

Copyright: (c) 2021 by the authors. Licensee MDPI, Basel, Switzerland. This article is an open access article distributed under the terms and conditions of the Creative Commons Attribution (CC BY) license (https:/ / creativecommons.org/licenses/by/ $4.0 /)$.

\begin{abstract}
Nanoparticles (NPs) recently emerged as new chemical elicitors acting as signaling agents affecting several processes in plant metabolism. The aim of this work was to investigate the impact of the addition of copper oxide $(\mathrm{CuO})$, zinc oxide $(\mathrm{ZnO})$ and iron oxide $\left(\mathrm{Fe}_{3} \mathrm{O}_{4}\right) \mathrm{NPs}(<100 \mathrm{~nm})$ at different concentrations $(1,5$ and $10 \mathrm{mg} / \mathrm{L})$ to the culture media on several morphological, physiological and -biochemical parameters of in vitro shoot cultures of Lavandula viridis L'Hér and Thymus lotocephalus G. López and R. Morales (Lamiaceae), as well as on phenolic profile and bioactivity (antioxidant and enzyme inhibition capacities). Although some decreases in shoot number and length were observed in response to NPs, biomass production was not affected or was improved in both species. Most NPs treatments decreased total chlorophyll and carotenoid contents and increased malondialdehyde levels, an indicator of lipid peroxidation, in both species. HPLC-HR-MS analysis led to the identification of thirteen and twelve phenolic compounds, respectively, in L. viridis and T. lotocephalus extracts, being rosmarinic acid the major compound found in all the extracts. $\mathrm{ZnO}$ and $\mathrm{Fe}_{3} \mathrm{O}_{4}$ NPs induced an increase in total phenolic and rosmarinic acid contents in T. lotocephalus extracts. Additionally, some NPs treatments also increased antioxidant activity in extracts from this species and the opposite was observed for L. viridis. The capacity of the extracts to inhibit tyrosinase, acetylcholinesterase and butyrylcholinesterase enzymes was not considerably affected. Overall, NPs had a significant impact on different parameters of L. viridis and T. lotocephalus in vitro shoot cultures, although the results varied with the species and NPs type.
\end{abstract}

Keywords: antioxidant activity; enzymes inhibition; in vitro culture; nanoparticles; phenolics; rosmarinic acid

\section{Introduction}

Natural resources contain a great diversity of chemical molecules produced as a response to several biotic and abiotic factors affecting organisms' biosynthetic pathways. Among natural sources, plants have a special relevance due to their great diversity of molecules with beneficial biological activities important to humans and their single structural features, namely safety, multi-target spectrum and metabolite likeness [1,2]. Lamiaceae is a family of plant species with wide distribution in different ecosystems comprising species with great economic value, due to their potential as ornamentals, culinary herbs and due to the production of valuable bioactive compounds [3,4]. Lavandula and Thymus are 
two of the most important genera within Lamiaceae family, comprising species producing high-value phytochemicals as volatiles (essential oils) and phenolics [5-7]. Lavandula viridis L'Hér and Thymus lotocephalus G. Lopez and R. Morales are Mediterranean aromatic species endemic to the south-west Iberian Peninsula and the Algarve region (South of Portugal), respectively. Both species produce bioactive phytochemicals with antioxidant and enzyme inhibiting properties [8-14].

Lately, more attention is dedicated to in vitro plant tissue culture systems as means for bioactive compounds production [2,15] including from Lavandula and Thymus species [14,16]. In vitro culture techniques allow the rapid propagation of disease-free plants, genetic transformation of plants, and also the rapid production of notable secondary metabolites [15]. The production of plant-derived metabolites in vitro presents some advantages in comparison with traditional systems, such as the rapid production, low burden of human pathogens and scalability, and the production throughout the year with no seasonal restrictions $[2,15,17]$. This method allows the mass production of plant material without negative impact on natural populations and, thus is particularly important for species that are threatened or at the risk of extinction as is the case of T. lotocephalus. Many reports suggest that plant natural habitats are being rapidly lost due to many factors including urbanism, climate change and agriculture. Plant biotechnology using tissue culture techniques may ensure the ex situ conservation of those plants and concurrently provide a sustainable method for the production of valuable bioactives [2].

Nanotechnology, which involves the use of many nanomaterials with dimensions in the range from 1 to $100 \mathrm{~nm}$ (nanoparticles, nanocoatings, nanofilms, etc.), has currently swarmed over all areas of life, having enormous applications in the fields of food, cosmetics, and medicine. Among nanomaterials, nanoparticles (NPs) have unique properties possessing specific physico-chemical properties attributed to their smaller size, large surface area and high reactivity compared to their bulk counterparts [18]. Recent studies showed also encouraging inputs from nanotechnology in plant biotechnology including plant tissue culture [19]. The application of NPs has been successfully reported in plant regeneration, callus induction, genetic transformation, elimination of microbial contaminants, and particularly on secondary metabolite production [19]. NPs emerged as new chemical elicitors acting as signalling agents affecting several morphological, physiological and biochemical processes in plant metabolism $[19,20]$. Elicited in vitro plant cultures are recently gaining more interest for their potential in the production of high-value secondary metabolites. Various biological, chemical and physical elicitors can trigger a signal transduction cascade of defense systems in plants mediating the expression of genes linked to the biosynthesis of secondary metabolites [21]. Despite the insights achieved through some previous studies on in vitro culture of L. viridis and T. lotocephalus [22,23] and the feasibility of in vitro-produced shoots for the production of secondary metabolites $[11,12,14]$, to the best of our knowledge, there are no previous reports on the effects of NPs on in vitro culture of these species nor in their potential impact on elicitation of secondary metabolites with biological properties. As NPs can act as chemical elicitors and copper, zinc and iron are microelements essential for plant growth and development, the present study aimed to elucidate if copper oxide $(\mathrm{CuO})$, zinc oxide $(\mathrm{ZnO})$ and iron oxide $\left(\mathrm{Fe}_{3} \mathrm{O}_{4}\right) \mathrm{NPs}(<100 \mathrm{~nm})$, at different concentrations (1,5 and $10 \mathrm{mg} / \mathrm{L})$, can affect morphological, physiological and biochemical features of in vitro shoots of these species, as well as the production of phenolic compounds, antioxidant and enzyme inhibitory activities.

\section{Results and Discussion}

\subsection{Biometric and Physiological Features}

Several biotic and abiotic elicitors acting as stress agents can affect the growth of in vitro cultures. Both stimulatory and inhibitory effects of the addition of different metal oxide (e.g., $\mathrm{CuO}, \mathrm{ZnO}$ and $\mathrm{NiO}$ ) NPs to the culture medium on shoot growth have been reported [24-26]. As frequently reported, in this work the effect of the addition of NPs to the culture medium depended on the type of NP tested and the plant species. In $L$. 
viridis the number of shoots produced was not significantly affected by $\mathrm{Fe}_{3} \mathrm{O}_{4} \mathrm{NPs}$ at any dose used (average of 4.26 in the control and 3.92-4.41 in $\mathrm{Fe}_{3} \mathrm{O}_{4} \mathrm{NPs}$ ) but was negatively affected by $\mathrm{CuO}$ (from 2.84 to 3.46) and $\mathrm{ZnO}$ (2.33-3.07) NPs in a concentration-dependent manner (Table 1). Although the three NPs tested negatively affected shoot length in $L$. viridis, the biomass produced (fresh and dry mass) in NPs-treated cultures was similar or even higher than the obtained with the control medium (Table 1). In T. lotocephalus, $\mathrm{ZnO}$ NPs did not affect any growth parameter, and $\mathrm{Fe}_{3} \mathrm{O}_{4} \mathrm{NPs}$ significantly improved shoot number at 5 and $10 \mathrm{mg} / \mathrm{L}(16.28,31.62$ and 26.35 in the control, NPs at 5 and $10 \mathrm{mg} / \mathrm{L}$, respectively) and biomass production at $5 \mathrm{mg} / \mathrm{L}$ (fresh weight: $1902.07 \mathrm{mg}$ in the control and $4854.29 \mathrm{~g}$ in $\mathrm{Fe}_{3} \mathrm{O}_{4} \mathrm{NPs}$; dry weight: 174.43 and 343.31, respectively). On the other hand, $\mathrm{CuO}$ NPs significantly reduced shoot number (from 16.28 in the control to 8.19-11.19 in CuO NPs) and length (from $38.30 \mathrm{~mm}$ to $17.54-29.44 \mathrm{~mm}$ ) but did not affect biomass production (Table 1). In line with these results, the growth inhibitory effect of several $\mathrm{ZnO}$ and $\mathrm{CuO}$ NPs on different types of in vitro cultures has been reported by different authors. $\mathrm{ZnO}$ NPs reduced the growth of Solanum melongena seedlings [27]. High concentrations of $\mathrm{CuO}$ and $\mathrm{ZnO}$ NPs also reduced shoot and root growth of in vitro grown seedlings of Abelmoschus esculentus (okra) [24]. High concentrations of CuO NPs reduced shoot and root growth in Oryza sativa plants [28]. Several investigations demonstrated that the effects of NPs on growth are very dependent on the concentration used. For instance, Javed et al. [29] reported a positive role of $\mathrm{ZnO} N \mathrm{Ns}$ in the growth of Stevia rebaudiana shoots up to $1 \mathrm{mg} / \mathrm{L}$ but higher concentrations caused a significant reduction in growth parameters. In this work, overall $\mathrm{ZnO}$ and $\mathrm{CuO}$ NPs harmed the shoot multiplication at all concentrations tested however did not significantly affect biomass production. On the other hand, $\mathrm{Fe}_{3} \mathrm{O}_{4} \mathrm{NPs}$ slightly improved shoot growth (Table 1). It is widely accepted that mineral composition of the culture medium influences parameters such as cellular differentiation, phenotypic characteristics, plant growth and development in in vitro conditions and that controlling micronutrients levels is more important in in vitro conditions than in vivo [30]. In this sense, despite being a micronutrient, iron demonstrated a great influence on in vitro plant growth and, when applied in the form of nanoparticles, the smaller the diameter of iron the easiest it is absorbed, facilitating the plant's nutritional balance [31,32]. Moreover, it has been shown that the application of nano-iron oxide increases the absorption and uptake of important macronutrients in several plant species [32-34]. On the other hand, the addition of other NPs such as $\mathrm{Au}$ and $\mathrm{Ag}$ at different concentrations positively affected in vitro growth and development of another Lavandula species, L. angustifolia [35].

It has been observed that NPs induced chloroplast disorganization, namely reducing the numbers of thylakoids and grana, resulting in lower chlorophyll amounts $[24,36,37]$. In agreement with these observations, most NPs treatments tested in this study caused a decrease in total chlorophyll and carotenoid contents in shoots of both species (Table 1). In the case of $\mathrm{CuONPs}$, this negative effect was strongly accentuated with the increase of NPs concentration (Table 1). El-Mahdy and Elazab [25] reported that the effect of ZnO NPs on photosynthetic pigments contents of shoots of two pomegranate cultivars strongly depended on NPs concentration. NPs significantly increased photosynthetic pigments contents at 1 and $2.5 \mathrm{mg} / \mathrm{L}$, but reduced those contents at 7 and $10 \mathrm{mg} / \mathrm{L}$. 


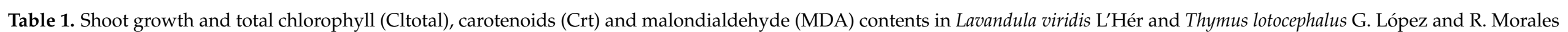
shoots cultured in media with 0 (control), 1, 5 or $10 \mathrm{mg} / \mathrm{L}$ of $\mathrm{CuO}, \mathrm{ZnO}$ and $\mathrm{Fe}_{3} \mathrm{O}_{4}$ nanoparticles.

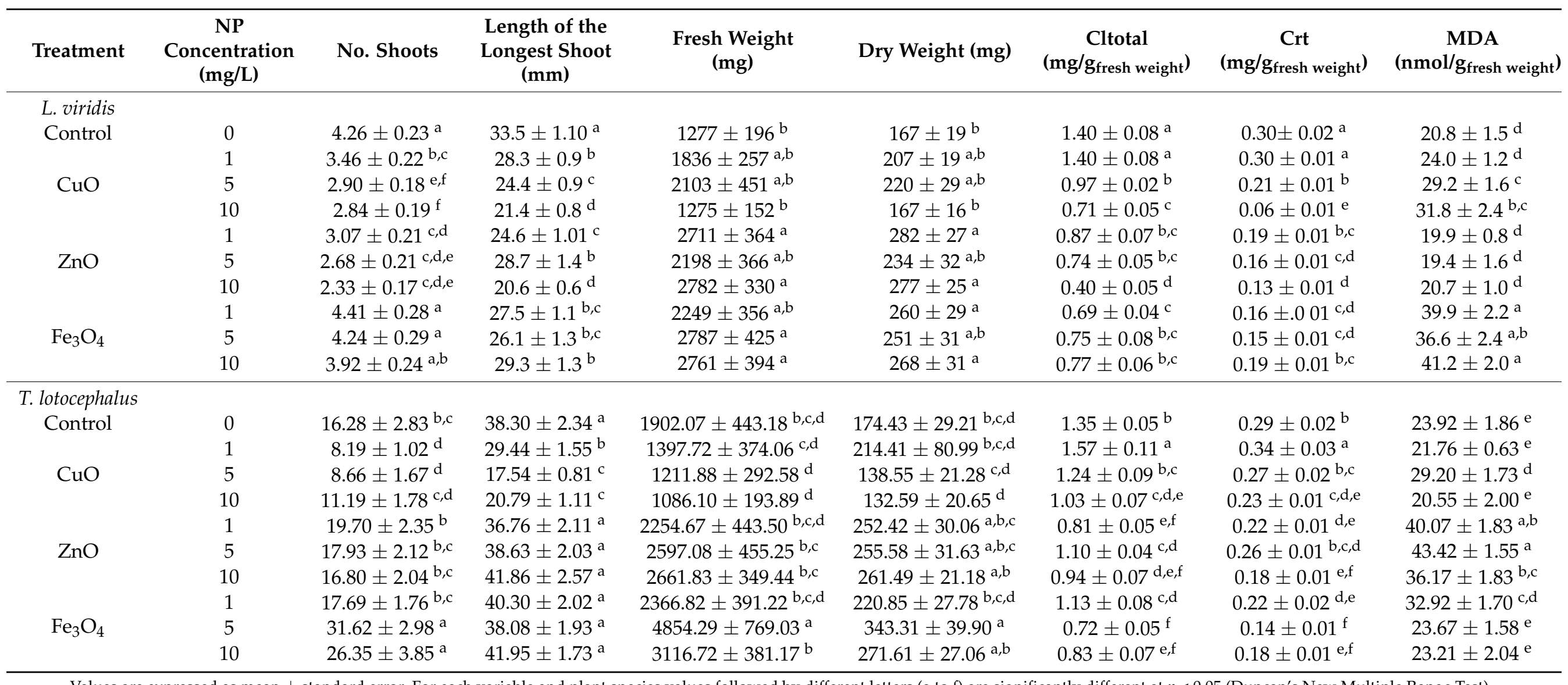

Values are expressed as mean \pm standard error. For each variable and plant species values followed by different letters (a to f) are significantly different at $p<0.05$ (Duncan's New Multiple Range Test). 
Under stress conditions, free radical production is stimulated which can cause an overproduction of MDA, a major peroxidation product of polyunsaturated fatty acids, and thus, MDA levels are frequently used as markers of oxidative damage. In this study, $\mathrm{CuO}$ NPs at 5 and $10 \mathrm{mg} / \mathrm{L}\left(29.24\right.$ and $\left.31.78 \mathrm{nmol} / \mathrm{g}_{\text {fresh weight }}\right)$, and $\mathrm{Fe}_{3} \mathrm{O}_{4} \mathrm{NPs}$ at all concentrations tested $\left(39.86,36.57\right.$ and $\left.41.23 \mathrm{nmol} / \mathrm{g}_{\text {fresh weight }}\right)$ significantly increased MDA accumulation in comparison with the control in L. viridis $\left(20.84 \mathrm{nmol} / \mathrm{g}_{\text {fresh weight }}\right)$. On the other hand, in T. lotocephalus increases in MDA levels were observed with $\mathrm{CuO}$ $\mathrm{NPs}$ at $5 \mathrm{mg} / \mathrm{L}\left(29.2 \mathrm{nmol} / \mathrm{g}_{\text {fresh weight }}\right), \mathrm{ZnO} \mathrm{NPs}$ at all concentrations $(40.07,43.42$ and $36.17 \mathrm{nmol} / \mathrm{g}_{\text {fresh weight, }}$ at 1,5 and $10 \mathrm{mg} / \mathrm{L}$, respectively), and $\mathrm{Fe}_{3} \mathrm{O}_{4} \mathrm{NPs}$ at $1 \mathrm{mg} / \mathrm{L}$ $\left(32.92 \mathrm{nmol} / \mathrm{g}_{\text {fresh weight }}\right)$ compared with the control $\left(23.92 \mathrm{nmol} / \mathrm{g}_{\text {fresh weight }}\right)$. The increase of lipid peroxidation in response to $\mathrm{CuO}, \mathrm{ZnO}$ and $\mathrm{Fe}_{3} \mathrm{O}_{4}$ NPs has been observed in several species [24,28,38,39]. According to Da Costa and Sharma [28] cell membrane is even the first target of $\mathrm{CuO}$ NPs toxicity. Chang et al. [39] reported that CuO-NPs can cause genotoxicity in plant tissues if the $\mathrm{Cu}$ amounts exceed the physiological tolerance range because $\mathrm{Cu}$ is indispensable to maintain homeostasis in living systems. Additionally, $\mathrm{Zn}$ is another essential microelement for plant growth and development, it stimulates protein synthesis and chlorophyll biosynthesis, and plays an important role in regulatory and physiological processes [25]. However, at high concentrations, $\mathrm{Zn}$ can induce lipid peroxidation as well as the production of $\mathrm{H}_{2} \mathrm{O}_{2}$ leading to the reduction of photosynthetic pigments biosynthesis [40].

\subsection{Phenolic Profile Analyzed by HPLC-HR-MS}

Phenolic compounds emerge as one of the main groups of plant secondary metabolites. They are linked with biotic and abiotic stress responses in plants and are the main responsible for the biological properties of plants, namely antioxidant activity. In addition to other well-known biotic and abiotic elicitors, NPs recently emerged as a new class of elicitors that can activate enzymatic pathways responsible for the production of secondary metabolites. Nevertheless, attempts to evaluate the impact of these submicron size particles on phenolics production are still limited. In this study, the phenolic profiles of L. viridis and T. lotocephalus extracts from shoots cultured in media with different NPs treatments were analyzed for the first time by HPLC-HR-MS. A total of thirteen (eleven phenolic acids, a flavonoid and a coumarin derivative) and twelve (ten phenolic acids, a flavonoid and a coumarin derivative) compounds were identified in L. viridis and T. lotocephalus extracts, respectively (Tables S1, S2 and 2). Caffeic acid hexosides (I and II), fertaric acid, salvianolic acid derivatives, and herniarin were identified for the first time in L. viridis and $O$-caffeoylquinic acid, caffeic acid hexosides, salvianolic acid derivatives, luteolin-7$\mathrm{O}$-glucuronide and herniarin in T. lotocephalus. Apigenin and luteolin-7-O-glucuronide were the only flavonoid compounds detected in extracts from L. viridis and T. lotocephalus, respectively. The flavonoid luteolin was previously identified in L. viridis [12,41] and T. lotocepahalus [12] extracts but was not found in this study. The coumarin derivative herniarin was also found in all the extracts from both species (Table 2). 


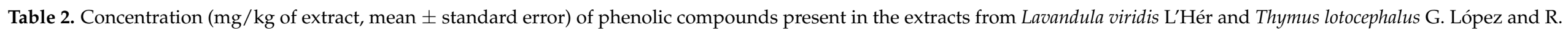
Morales shoots cultured in media with 0 (control), 1, 5 or $10 \mathrm{mg} / \mathrm{L}$ of $\mathrm{CuO}, \mathrm{ZnO}$ and $\mathrm{Fe}_{3} \mathrm{O}_{4}$ nanoparticles.

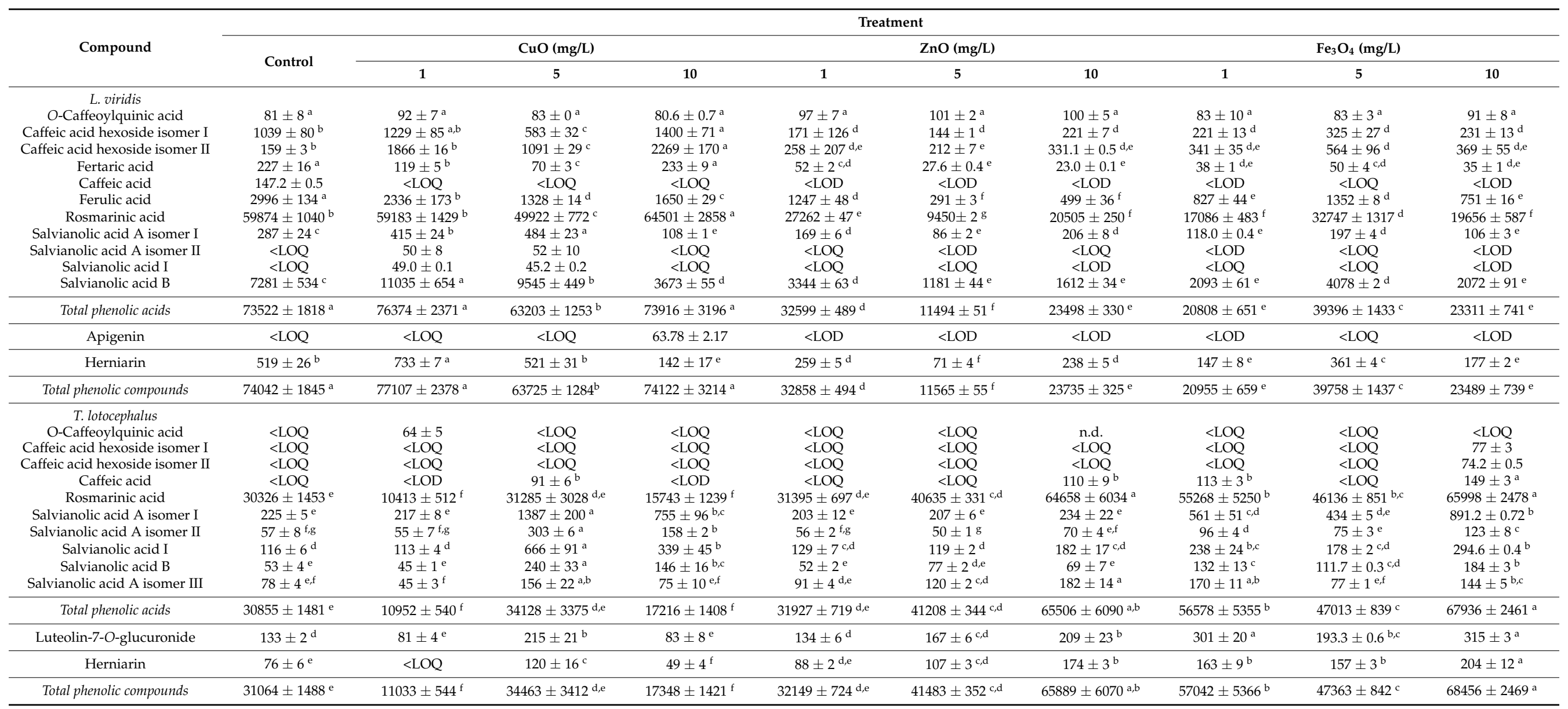

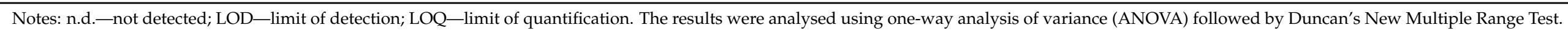

Different letters ( $\mathrm{a}$ to g) in each row and for each phenolic compound mean significant differences $(p<0.05)$ among treatments. 
The hydroxycinnamic acid rosmarinic acid was outstandingly the major compound identified in the extracts of L. viridis (between $9450 \mathrm{mg} / \mathrm{kg}$ in $5 \mathrm{mg} / \mathrm{L} \mathrm{ZnO}$ and $64,501 \mathrm{mg} / \mathrm{kg}$ in $10 \mathrm{mg} / \mathrm{L} \mathrm{CuO}$ ) and T. lotocephalus (between 10,413 mg/ $\mathrm{kg}$ in $1 \mathrm{mg} / \mathrm{L} \mathrm{CuO}$ and $65,998 \mathrm{mg} / \mathrm{kg}$ in $10 \mathrm{mg} / \mathrm{L} \mathrm{Fe}_{3} \mathrm{O}_{4}$ ) (Table 2) as reported in previous studies with these species $[8,11,12,14]$. Rosmarinic acid contents in control extracts from L. viridis were significantly higher $(59,874 \mathrm{mg} / \mathrm{kg})$ than the values previously obtained by Costa et al. [12] (471.20, 41,293 and $32,046 \mathrm{mg} / \mathrm{kg}$ in water, water/ethanol and ethanol extract, respectively). In T. lotocephalus, rosmarinic acid content was higher $(30,326 \mathrm{mg} / \mathrm{kg})$ than the values obtained by Costa et al. [11] (23,100 and 22,600 mg/ $\mathrm{kg}$ in water/ethanol and ethanol extract, respectively) but lower than the recently observed by Gonçalves et al. [14] $(48,610 \mathrm{mg} / \mathrm{kg}$ in methanol extract).

The second most abundant compounds found in the extracts were salvianolic acid $\mathrm{B}$ in L. viridis (between $1181 \mathrm{mg} / \mathrm{kg}$ in $5 \mathrm{mg} / \mathrm{L} \mathrm{ZnO}$ and $11,035 \mathrm{mg} / \mathrm{kg}$ in $1 \mathrm{mg} / \mathrm{L} \mathrm{CuO}$ ) and salvianolic acid A isomer I in T. lotocephalus (between $203 \mathrm{mg} / \mathrm{kg}$ in $1 \mathrm{mg} / \mathrm{L} \mathrm{ZnO}$ and $1387 \mathrm{mg} / \mathrm{kg}$ in $5 \mathrm{mg} / \mathrm{L} \mathrm{CuO}$ ). Although being identified for the first time in these species, salvianolic acids were found in other Lavandula [42,43] and Thymus [44-46] species. Studies from Taghouti et al. [44] with several endemic Iberian Thymus species highlight the importance of salvianolic acids levels in Thymus extracts and their bioactivity.

In which concerns the effect of NPs on phenolics production, as observed for biometric features, the results depend on the species and NPs treatment. Although in L. viridis rosmarinic acid content was significantly enhanced by $\mathrm{CuO} \mathrm{NPs} \mathrm{at} 10 \mathrm{mg} / \mathrm{L}$ and salvianolic acid $B$ by the same NPs at 1 and $5 \mathrm{mg} / \mathrm{L}$, overall, total phenolic compounds were negatively affected by NPs, especially using $\mathrm{ZnO}$ and $\mathrm{Fe}_{3} \mathrm{O}_{4}$ NPs. On the other hand, NPs treatments including $\mathrm{ZnO}$ at 5 and $10 \mathrm{mg} / \mathrm{L}$ and $\mathrm{Fe}_{3} \mathrm{O}_{4}$ at all concentrations, significantly increased total phenolic compounds in T. lotocephalus as well as rosmarinic acid amounts. The effect of metal NPs on phenolics production is variable. ZnO NPs also induced an increase in total phenolic and flavonoid contents in callus of Stevia rebaudiana, but determined by spectrophotometric assays [47] and in cell suspension cultures from Brassica nigra seedlings [48]. ZnO NPs stimulated the production of thymol and carvacrol in callus cultures of Thymus species and Zataria multiflora [49]. Additionally, $\mathrm{Fe}_{3} \mathrm{O}_{4} \mathrm{NPs}$ increased total phenolic, flavonoid, anthocyanin, and lignin contents in cell suspension cultures of Dracocephalum polychaetum and also, the contents of several phenolics like naringin, rutin, quercetin, apigenin, rosmarinic acid, thymol and carvacrol [50]. In T. lotocephalus caffeic acid hexoside was only found in quantifiable amounts in samples of shoots cultured in medium with $\mathrm{Fe}_{3} \mathrm{O}_{4} \mathrm{NPs}$ at $10 \mathrm{mg} / \mathrm{L}$. The highest contents of salvianolic acids in this species were obtained in extracts from shoots cultured in a medium with $5 \mathrm{mg} / \mathrm{L}$ of $\mathrm{CuO}$ NPs (Table 2). Abdel-Wahab et al. [38] also reported increases in phenolic contents cultured with $\mathrm{CuO}$ NPs in callus cultures of Solanum nigrum.

\subsection{Antioxidant and Enzymes Inhibitory Activities: Correlation with Phenolic Composition}

A plant extract is a complex mixture of several compounds with different abilities to terminate radical chain processes and, thus, its antioxidant capacity must be assessed by more than one assay. In this study the antioxidant activity was assessed by four chemical assays: one HAT-based method [oxygen radical absorbance capacity (ORAC)] and three mixedmode (ET- and HAT-based) methods [2,2'-Azino-bis (3-ethylbenzothiazoline-6-sulfonic acid) (ABTS), 2,2-diphenyl-1-picrylhydrazyl (DPPH) and ferric reducing antioxidant power (FRAP)]. The ORAC assay measures the radical chain breaking capacity of antioxidants by determining the blocking-up of peroxyl radicals generated oxidation. ABTS and DPPH measure the scavenging ability toward stable free radicals and FRAP assay measures the ability of the extracts to reduce $\mathrm{Fe}^{3+}$ to $\mathrm{Fe}^{2+}$. The antioxidant activity measured by ABTS (185 \pm 1 and $101.3 \pm 0.6 \mathrm{mg}_{\mathrm{TE}} / \mathrm{g}_{\text {extract, }}$, respectively for L. viridis and T. lotocephalus extracts), DPPH (167 \pm 7 and $\left.86 \pm 2 \mathrm{mg}_{\mathrm{TE}} / \mathrm{g}_{\text {extract }}\right), \mathrm{FRAP}\left(229 \pm 3\right.$ and $125 \pm 1 \mathrm{mg}$ AAE $\left./ \mathrm{g}_{\text {extract }}\right)$ and ORAC (619 \pm 31 and $\left.358 \pm 35 \mathrm{mg}_{\mathrm{TE}} / \mathrm{g}_{\text {extract }}\right)$ assays of extracts from shoots cultured in the control medium was greater in L. viridis than in T. lotocephalus. The antioxidant activity 
values previously obtained [11,12] with ABTS and ORAC assays of water/ethanol extracts from in vitro cultured shoots of L. viridis $\left(213.78 \pm 3.06\right.$ and $710.28 \pm 40.54 \mathrm{mg}$ TE $/ \mathrm{g}_{\text {extract, }}$ respectively) and $T$. lotocephalus (140.91 \pm 3.90 and $\left.605.70 \pm 69.08 \mathrm{mg}_{\mathrm{TE}} / \mathrm{g}_{\text {extract }}\right)$ were slightly higher than those of the methanol extracts investigated in this work. Gonçalves et al. [14] also evaluated the antioxidant activity of a methanol extract from T. lotocephalus shoots with ABTS $\left(75.51 \pm 0.89 \mathrm{mg}_{\mathrm{TE}} / \mathrm{g}_{\text {extract }}\right), \mathrm{DPPH}\left(105.98 \pm 8.37 \mathrm{mg}_{\mathrm{TE}} / \mathrm{g}_{\text {extract }}\right), \mathrm{FRAP}$ $\left(101.18 \pm 4.33 \mathrm{mg}_{\mathrm{AAE}} / \mathrm{g}_{\text {extract }}\right)$ and ORAC $\left(454.36 \pm 16.54 \mathrm{mg} \mathrm{TE} / \mathrm{g}_{\text {extract }}\right)$ assays and the results are in the same range as those obtained in this work.

Regarding the impact of NPs on the antioxidant activity, it was observed that NPs treatments, particularly of $\mathrm{ZnO}$ and $\mathrm{Fe}_{3} \mathrm{O}_{4}$, lead to the decrease of antioxidant activity of $L$. viridis extracts probably as a result of the reduction in phenolic compounds (Table 2). On the other hand, $\mathrm{ZnO}, \mathrm{CuO}$ and $\mathrm{Fe}_{3} \mathrm{O}_{4} \mathrm{NPs}$ at some concentrations induced an increase in T. lotocephalus antioxidant activity (Figure 1). As observed for total phenolic contents, the highest free radical scavenging activity $\left(\mathrm{ABTS}^{\bullet+}\right.$ and $\left.\mathrm{DPPH}^{\bullet}\right)$, as well as ferric reducing and peroxyl radical's neutralization capacities of T. lotocephalus extracts, were obtained from shoots cultured with $10 \mathrm{mg} / \mathrm{L}$ of $\mathrm{Fe}_{3} \mathrm{O}_{4} \mathrm{NPs}\left(189 \pm 34 \mathrm{mg} \mathrm{TE} / \mathrm{g}_{\text {extract }}, 226 \pm 9 \mathrm{mg}\right.$ TE $/ \mathrm{g}_{\text {extract }}$, $259 \pm 8 \mathrm{mg}_{\mathrm{AAE}} / \mathrm{g}_{\text {extract }}$ and $711 \pm 51 \mathrm{mg}_{\mathrm{TE}} / \mathrm{g}_{\text {extract}}$, respectively). The greatest impact of NPs on the antioxidant activity in this species was measured with ORAC assay (Figure 1). This can be related to the different mode of action of this HAT-based assay that uses a fluorescent probe to compete with antioxidants for peroxyl radicals generated by the decomposition of 2,2'-azobis(2-methylpropionamidine) dihydrochloride (AAPH).

In this work $\mathrm{CuO}$ NPs at the concentrations tested did not improve the DPPH radical scavenging activity in L. virids and T. lotocephalus. Ahmad et al. [51] observed the highest DDPH scavenging activity of Stevia rebaudiana regenerants cultured with these NPs at $2 \mathrm{mg} / \mathrm{L}$. Additionally, $\mathrm{CuO}$ and $\mathrm{ZnO} \mathrm{NPs}$ also caused a significant increase in total antioxidant capacity, reducing power and DPPH radical scavenging capacity of the extracts from shoots of the same species $[29,52]$. There are no studies about the impact of the same type of NPs on the antioxidant activity of plants from the genus Lavandula and Thymus however, it was reported that Ag and Au NPs increased the ABTS free radical scavenging capacity in cultures of L. angustifolia [35].

A strong correlation was observed between antioxidant results obtained in the four assays and total phenolic contents of extracts from both species $(p<0.01)$ (Table 3$)$ indicating that these compounds are the main ones involved in the antioxidant effects of these species. Moreover, in L. viridis a high correlation was also achieved between the contents of most of the individual phenolic compounds found in the extracts and the antioxidant results. In T. lotocephalus this correlation was observed for caffeic acid, rosmarinic acid, salvianolic acid A isomer III, luteolin-7-O-glucuronide and herniarin (Table 3). The correlation between phenolic compounds and antioxidant activity has been frequently reported for many species from Thymus and Lavandula genus $[14,43,44]$. Phenolics are plant secondary metabolites generally associated with plant defense mechanisms. They can act as antioxidants to scavenge ROS and thus, increase the phenolics production can be a strategy developed by plants to cope with stress-induced by NPs. Many biotic and abiotic stress factors can lead to oxidative stress induction in plants and stimulate the metabolism and accumulation of phenolic compounds [21]. Additionally, some studies indicated that the oxidative stress induced by the metal NPs in plants can influence the production of secondary metabolites, but this is still poorly understood $[53,54]$. 


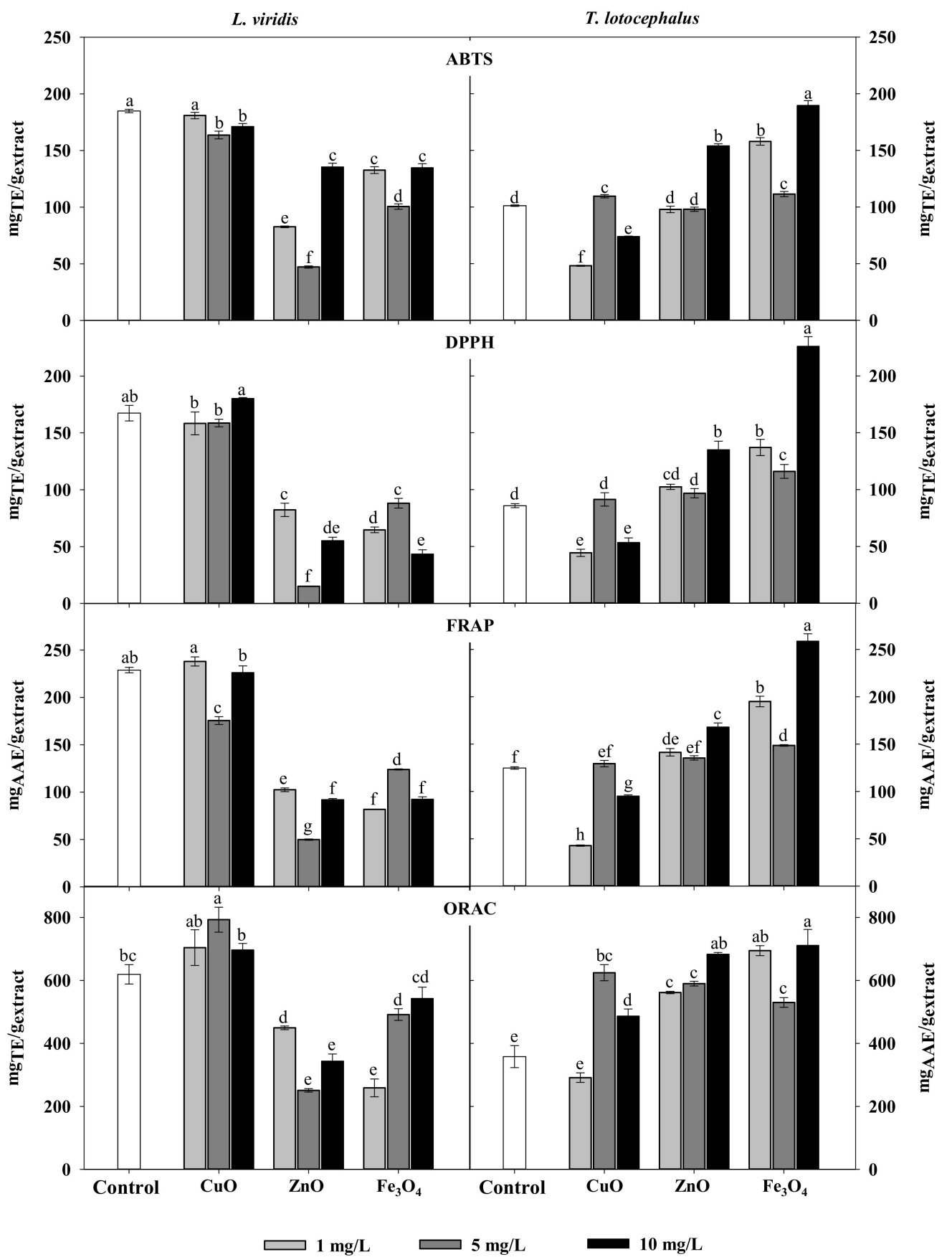

Figure 1. Antioxidant activity determined by ABTS, DPPH, FRAP, and ORAC assays of extracts from Lavandula viridis L'Hér and Thymus lotocephalus G. López and R. Morales shoots cultured in media with 0 (control), 1, 5 or $10 \mathrm{mg} / \mathrm{mL}$ of $\mathrm{CuO}, \mathrm{ZnO}$ and $\mathrm{Fe}_{3} \mathrm{O}_{4}$ nanoparticles. Values are expressed as mean $\pm \mathrm{SE}(n=3)$. In each graph bars followed by different letters $(\mathrm{a}-\mathrm{f})$ are significantly different at $p<0.05$ (Duncan's New Multiple Range Test). ABTS: 2,2'-azino-bis(3-ethylbenzothiazoline-6sulfonic acid); DPPH: 2,2-diphenyl-1-picrylhydrazyl; FRAP: ferric reducing antioxidant power; ORAC: oxygen radical absorbance capacity. 
Table 3. Pearson's correlation coefficients between antioxidant activity measured by the different assays (DPPH, FRAP, ABTS, and ORAC), enzyme inhibitory activities (AChE, BChE, and Tyr), total and individual phenolic compounds determined by HPLC-HR-MS.

\begin{tabular}{|c|c|c|c|c|c|c|c|}
\hline \multirow[t]{2}{*}{ Phenolic Compounds } & \multicolumn{4}{|c|}{ Antioxidant Activity } & \multicolumn{3}{|c|}{ Enzyme Inhibitory Activity } \\
\hline & ABTS & DPPH & FRAP & ORAC & Tyr & $\mathrm{AChE}$ & BChE \\
\hline \multicolumn{8}{|l|}{ L. viridis } \\
\hline O-Caffeoylquinic acid & $-0.492 *$ & $-0.519 *$ & -0.443 & -0.432 & $-0.517 *$ & -0.177 & $-0.542 *$ \\
\hline Caffeic acid hexoside isomer I & $0.778^{* *}$ & $0.879 * *$ & $0.941^{* *}$ & $0.766^{* *}$ & $0.440 *$ & $0.475^{*}$ & $0.897^{* *}$ \\
\hline Caffeic acid hexoside isomer II & $0.783^{* *}$ & $0.903^{* *}$ & $0.942 * *$ & $0.788^{* *}$ & $0.501 *$ & $0.515 *$ & $0.910^{* *}$ \\
\hline Fertaric acid & $0.674^{* *}$ & $0.824^{* *}$ & $0.853^{* *}$ & $0.631^{* *}$ & 0.284 & $0.605^{* *}$ & $0.785^{* *}$ \\
\hline Ferulic acid & $0.702^{* *}$ & $0.841^{* *}$ & $0.881^{* *}$ & $0.712^{* *}$ & 0.402 & 0.392 & $0.733^{* *}$ \\
\hline Rosmarinic acid & $0.811^{* *}$ & $0.975^{* *}$ & $0.985^{* *}$ & $0.876^{* *}$ & $0.632 * *$ & $0.508^{*}$ & $0.927^{* *}$ \\
\hline Salvianolic acid A isomer I & $0.576^{* *}$ & $0.613^{* *}$ & $0.591^{* *}$ & $0.669 * *$ & $0.655^{* *}$ & -0.025 & $0.552 *$ \\
\hline Salvianolic acid B & $0.669 * *$ & $0.776^{* *}$ & $0.791^{* *}$ & $0.817^{* *}$ & $0.645^{* *}$ & 0.102 & $0.745^{* *}$ \\
\hline Herniarin & $0.614^{* *}$ & $0.662 * *$ & $0.704^{* *}$ & $0.698^{* *}$ & $0.540 *$ & 0.026 & $0.577^{* *}$ \\
\hline Total phenolic contents & $0.815^{* *}$ & $0.973^{* *}$ & $0.988^{* *}$ & $0.890^{* *}$ & $0.642^{* *}$ & $0.462 *$ & $0.926^{* *}$ \\
\hline \multicolumn{8}{|l|}{ T. lotocephalus } \\
\hline Caffeic acid & $0.910^{* *}$ & $0.970 * *$ & $0.932^{* *}$ & 0.032 & 0.310 & -0.049 & -0.203 \\
\hline Rosmarinic acid & $0.928^{* *}$ & $0.873^{* *}$ & $0.891^{* *}$ & $0.794^{* *}$ & $0.888^{* *}$ & -0.178 & 0.147 \\
\hline Salvianolic acid A isomer I & 0.243 & 0.172 & 0.255 & 0.394 & 0.065 & 0.269 & $0.851^{* *}$ \\
\hline Salvianolic acid A isomer II & 0.061 & -0.032 & 0.032 & 0.306 & -0.011 & 0.289 & $0.845^{* *}$ \\
\hline Salvianolic acid I & 0.132 & 0.020 & 0.104 & 0.382 & 0.037 & 0.221 & $0.842 * *$ \\
\hline Salvianolic acid B & 0.362 & 0.293 & 0.390 & $0.514 *$ & 0.214 & 0.232 & $0.828^{* *}$ \\
\hline Salvianolic acid A isomer III & $0.770 * *$ & $0.591^{* *}$ & $0.650 * *$ & $0.875^{* *}$ & $0.739^{* *}$ & 0.035 & 0.436 \\
\hline Luteolin-7-O-glucuronide & $0.914^{* *}$ & $0.858^{* *}$ & $0.887^{* *}$ & $0.795^{* *}$ & $0.693^{* *}$ & 0.214 & 0.401 \\
\hline Herniarin & $0.901^{* *}$ & $0.864^{* *}$ & $0.851^{* *}$ & $0.745^{* *}$ & $0.793^{* *}$ & -0.055 & 0.289 \\
\hline Total phenolic contents & $0.935^{* *}$ & $0.877^{* *}$ & $0.898^{* *}$ & $0.808^{* *}$ & $0.887^{* *}$ & -0.165 & 0.183 \\
\hline
\end{tabular}

DPPH: 2.2-diphenyl-1-picrylhydrazyl; FRAP: ferric reducing antioxidant power; ABTS: 2.2'-azino-bis(3-ethylbenzothiazoline-6-sulfonic acid); ORAC: oxygen radical absorbance capacity; Tyr: tyrosinase; AChE: acetylcholinesterase; BChE: butyrylcholinesterase. ${ }^{*}$ Correlation is significant $(p<0.05)$. ${ }^{* *}$ Correlation is significant $(p<0.01)$.

Plants have been considered an important source of compounds with the capacity to inhibit enzymes linked to several pathologies. In this study the inhibitory effects of plant extracts to modulate key enzymes involved in neurodegenerative disorders (tyrosinase, acetylcholinesterase, and butyrylcholinesterase) and melanogenesis (tyrosinase) were investigated. The results are summarized in Table 4. As far as our literature review can ascertain this is the first report about the effect of the NPs addition to the culture medium on the enzyme inhibitory capacity of plant extracts.

The extracts from both species showed a similar capacity to inhibit tyrosinase activity; from 10.31 to $17.49 \mathrm{mg}_{\mathrm{KAE}} / \mathrm{g}_{\text {extract }}$ in L. viridis and 11.46 to $18.36 \mathrm{in} \mathrm{mg}_{\mathrm{KAE}} / \mathrm{g}_{\text {extract }}$ in $T$. lotocephalus. Water extracts from L. viridis showed no inhibition of tyrosinase activity [55] and there are no previous reports describing the tyrosinase inhibitory capacity of T. lotocephalus extracts. $\mathrm{CuO}$ NPs at 5 and $10 \mathrm{mg} / \mathrm{L}$ significantly improved the anti-tyrosinase activity in L. viridis. On the other hand, in T. lotocephalus this activity increased with $\mathrm{ZnO}$ $\mathrm{NPs}$ at $10 \mathrm{mg} / \mathrm{L}$, and $\mathrm{Fe}_{3} \mathrm{O}_{4}$ at 1 and $10 \mathrm{mg} / \mathrm{L}$ (Table 4). 
Table 4. Enzymes inhibitory capacity of extracts from Lavandula viridis L'Hér and Thymus lotocephalus López and Morales shoots cultured in media with 0 (control), 1, 5 or $10 \mathrm{mg} / \mathrm{L}$ of $\mathrm{CuO}, \mathrm{ZnO}$ and $\mathrm{Fe}_{3} \mathrm{O}_{4}$ nanoparticles.

\begin{tabular}{|c|c|c|c|c|}
\hline Treatment & $\begin{array}{l}\text { NP Concentration } \\
(\mathrm{mg} / \mathrm{L})\end{array}$ & TYR $\left(\mathrm{mg}_{\mathrm{KAE}} / \mathrm{g}_{\text {extract }}\right)$ & $\operatorname{AChE}\left(\mathrm{mg}_{\mathrm{GE}} / \mathrm{g}_{\text {extract }}\right)$ & $\mathrm{BChE}\left(\mathrm{mg}_{\mathrm{GE}} / \mathrm{g}_{\text {extract }}\right)$ \\
\hline \multicolumn{5}{|l|}{ L. viridis } \\
\hline \multirow[t]{2}{*}{ Control } & 0 & $13.27 \pm 0.08^{c}$ & $4.43 \pm 0.08^{\mathrm{a}}$ & $9.74 \pm 0.89^{b}$ \\
\hline & 1 & $14.90 \pm 0.66^{\mathrm{b}, \mathrm{c}}$ & $3.44 \pm 0.19^{b}$ & $10.71 \pm 0.56^{b}$ \\
\hline \multirow[t]{3}{*}{$\mathrm{CuO}$} & 5 & $17.49 \pm 0.36^{\mathrm{a}}$ & $3.65 \pm 0.37^{b}$ & $10.26 \pm 0.26^{b}$ \\
\hline & 10 & $15.87 \pm 0.36^{\mathrm{a}, \mathrm{b}}$ & $4.58 \pm 0.26^{\mathrm{a}}$ & $12.33 \pm 0.31^{\mathrm{a}}$ \\
\hline & 1 & $13.99 \pm 0.47^{c}$ & $3.42 \pm 0.15^{b}$ & $4.04 \pm 0.21^{\mathrm{d}, \mathrm{e}}$ \\
\hline \multirow[t]{3}{*}{$\mathrm{ZnO}$} & 5 & $10.31 \pm 0.34^{\mathrm{d}}$ & $3.30 \pm 0.21^{b}$ & $2.49 \pm 0.51^{\mathrm{f}}$ \\
\hline & 10 & $13.35 \pm 0.31^{\mathrm{c}}$ & $3.34 \pm 0.23^{b}$ & $2.96 \pm 0.44^{\mathrm{e}, \mathrm{f}}$ \\
\hline & 1 & $13.64 \pm 0.41^{c}$ & $3.29 \pm 0.19^{b}$ & $5.12 \pm 0.52^{c, d}$ \\
\hline \multirow[t]{2}{*}{$\mathrm{Fe}_{3} \mathrm{O}_{4}$} & 5 & $14.60 \pm 0.66^{\mathrm{b}, \mathrm{c}}$ & $3.75 \pm 0.19^{b}$ & $4.95 \pm 0.23^{c, d}$ \\
\hline & 10 & $13.39 \pm 0.08^{c}$ & $3.63 \pm 0.26^{b}$ & $6.13 \pm 0.65^{c}$ \\
\hline \multicolumn{5}{|l|}{ T. lotocephalus } \\
\hline \multirow[t]{2}{*}{ Control } & 0 & $13.18 \pm 0.58^{\mathrm{d}, \mathrm{e}}$ & $3.28 \pm 0.19^{a, b, c}$ & $5.00 \pm 0.20^{\mathrm{d}}$ \\
\hline & 1 & $11.46 \pm 0.67 \mathrm{e}$ & $3.25 \pm 0.28^{\mathrm{a}, \mathrm{b}, \mathrm{c}}$ & $5.32 \pm 0.32^{\mathrm{c}, \mathrm{d}}$ \\
\hline \multirow[t]{3}{*}{$\mathrm{CuO}$} & 5 & $14.51 \pm 0.97^{\mathrm{b}, \mathrm{c}, \mathrm{d}}$ & $3.44 \pm 0.12^{\mathrm{a}, \mathrm{b}}$ & $8.75 \pm 0.60^{\mathrm{a}}$ \\
\hline & 10 & $14.16 \pm 0.31^{c, d, e}$ & $3.05 \pm 0.12^{b, c}$ & $6.36 \pm 0.28^{c}$ \\
\hline & 1 & $13.88 \pm 0.60$ c,d,e & $2.86 \pm 0.21^{\mathrm{c}}$ & $3.38 \pm 0.30^{\mathrm{e}}$ \\
\hline \multirow[t]{3}{*}{$\mathrm{ZnO}$} & 5 & $15.49 \pm 0.70^{a, b, c, d}$ & $3.05 \pm 0.11^{b, c}$ & $4.92 \pm 0.29^{\mathrm{d}}$ \\
\hline & 10 & $18.36 \pm 1.51^{\mathrm{a}}$ & $2.90 \pm 0.18^{b, c}$ & $6.51 \pm 0.67^{b, c}$ \\
\hline & 1 & $17.39 \pm 0.74^{\mathrm{a}, \mathrm{b}}$ & $3.74 \pm 0.13^{\mathrm{a}}$ & $4.92 \pm 0.61^{\mathrm{d}}$ \\
\hline \multirow[t]{2}{*}{$\mathrm{Fe}_{3} \mathrm{O}_{4}$} & 5 & $15.68 \pm 1.36^{\mathrm{a}, \mathrm{b}, \mathrm{c}, \mathrm{d}}$ & $2.90 \pm 0.11^{b, c}$ & $5.27 \pm 0.09^{\mathrm{c}, \mathrm{d}}$ \\
\hline & 10 & $16.81 \pm 1.04^{\mathrm{a}, \mathrm{b}, \mathrm{c}}$ & $3.22 \pm 0.12^{a, b, c}$ & $7.70 \pm 0.32^{b}$ \\
\hline
\end{tabular}

Values are expressed as mean \pm standard error. For each variable and plant species values followed by different letters (a to e) are significantly different at $p<0.05$ (Duncan's New Multiple Range Test). TYR: tyrosinase; AChE: acetylcholinesterase; BChE: butyrylcholinesterase; KAE: kojic acid equivalents; GE: galantamine equivalents.

A strong correlation was observed between the tyrosinase inhibitory activity of the extracts from both species and the total phenolic contents which is reported by other authors [56]. Additionally, this activity was strongly correlated with the amounts of some phenolic compounds including the major compound found in both species, rosmarinic acid. Indeed, this compound has been considered a good inhibitor of this enzyme $[57,58]$. The flavone luteolin-7-O-glucuronide identified in T. lotocephalus extracts appears to contribute also to the tyrosinase inhibitory effect of these extracts with a strong correlation. Recently, Mansinhos et al. [43] also reported a strong correlation between the contents of the flavone luteolin-7-O-glucoside and tyrosinase inhibition capacity of Lavandula pedunculata extracts.

The inhibitory capacities of the extracts against AChE and BChE ranged from

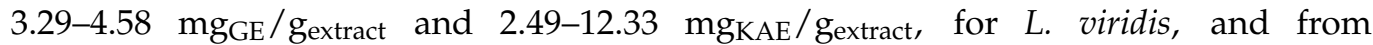
2.86-3.74 mg $\mathrm{mg}_{\mathrm{GE}} / \mathrm{g}_{\text {extract }}$ and 3.38-8.75 mg $\mathrm{mg}_{\mathrm{GE}} / \mathrm{g}_{\text {extract }}$ for T. lotocephalus. Overall, NPs treatments showed no positive effect on anti-AChE activity of extracts from both species and on anti-BChE activity of extracts from L. viridis. Otherwise, all NPs at the highest concentration significantly enhanced the capacity of $T$. lotocephalus extracts to inhibit BChE enzyme.

The AChE inhibition capacity of the extracts was moderately correlated with total phenolic contents in L. viridis and no correlation was found in the case of T. lotocephalus. In which concerns the correlation of anti-cholinesterase activities and the contents of rosmarinic acid, the major compound in the extracts of both species, the results varied depending on the species. It was found a correlation in the case of L. viridis, that is moderate for $\mathrm{AChE}(p<0.05)$ and strong for $\mathrm{BChE}(p<0.01)$, and no correction in the case of $T$. lotocephalus extracts. Curiously, in this species, a strong correlation was observed with 
the contents of several salvianolic acid derivatives and the inhibitory activity against BChE (Table 3).

\subsection{Principal Component Analysis (PCA)}

In the current study, PCA was employed to examine the effect of $\mathrm{ZnO}, \mathrm{CuO}$ and $\mathrm{Fe}_{3} \mathrm{O}_{4}$ NPs at different concentrations $(1-10 \mathrm{mg} / \mathrm{L})$ on in vitro culture of the two Lamiaceae species L. viridis and T. lotocephalus, including their impact on plant growth (shoot number, length of the longest shoot and fresh and dry weight of the biomass produced), photosynthetic pigments production (total chlorophyll and carotenoid contents), lipid peroxidation (MDA content), chemical composition (individual phenolic contents) and biological properties [antioxidant (ORAC, DPPH, FRAP and ABTS) and enzyme (AChE, BChE and tyrosinase) inhibitory activities]. The score plot (Figure 2A) represents extracts from L. viridis (red rhombuses) and T. lotocephalus (green squares) with the different types and concentrations of NPs, and the loading plot (Figure 2B) represents the contribution of each studied parameter to the score. The first two principal components (PC) accounted for $70.65 \%$ of the total variation in the dataset, $41.54 \%$ and $29.11 \%$ for the first and second respectively. In the score plot, the PC1 showed a clear grouping of the extracts by plant species, while the PC2 separated the samples by the type and concentration of the NP tested. In general, it should be noted that the T. lotocephalus extracts obtained from shoots cultured on medium with $\mathrm{Fe}_{3} \mathrm{O}_{4}$ at the highest and lowest concentrations, as well as with $\mathrm{ZnO}$ at the highest concentration, contained the highest amount of phenolics (total phenolics, phenolic acids and rosmarinic acid) and presented the highest antioxidant activities (by FRAP, DPPH and ORAC assays), as well as the greater inhibition of the tyrosinase enzyme. These samples represented the highest contribution in the negative PC1 and positive PC2 with elevated contents of hydroxycinnamic acids, salvianolic acids A (isomer II and III) and I, and the flavone luteolin-7-O-glucuronide, compounds that also characterize the T. lotocephalus extracts from shoots cultured with $\mathrm{Fe}_{3} \mathrm{O}_{4}, \mathrm{CuO}$ and $\mathrm{ZnO} N P s$ all at $5 \mathrm{mg} / \mathrm{L}$.

In the case of $L$. viridis extracts, a similar behavior was obtained with $\mathrm{CuO}$ NPs regardless of the concentration used. Furthermore, in general, extracts from these NPs presented the greatest response to the parameters studied and were similar to the control extract. The concentration of $10 \mathrm{mg} / \mathrm{L}$ of $\mathrm{CuO}$ improved the production of total phenolics (acids), and the contents of salvianolic acid B, O-caffeoylquinic, fertaric and ferulic acids, and the caffeic acid hexoside (isomers I and II). However, in the case of the hydroxycinnamic acids, these compounds were also in high contents when the shoots were cultured with $\mathrm{Fe}_{3} \mathrm{O}_{4} \mathrm{NPs}$ at $5 \mathrm{mg} / \mathrm{L}$. Furthermore, $\mathrm{CuO}$ and control L. viridis extracts presented higher antioxidant activity by ABTS and similar high activities for the other tested assays, and higher cholinesterase (BChE and AChE) inhibition than T. lotocephalus extracts. 
A

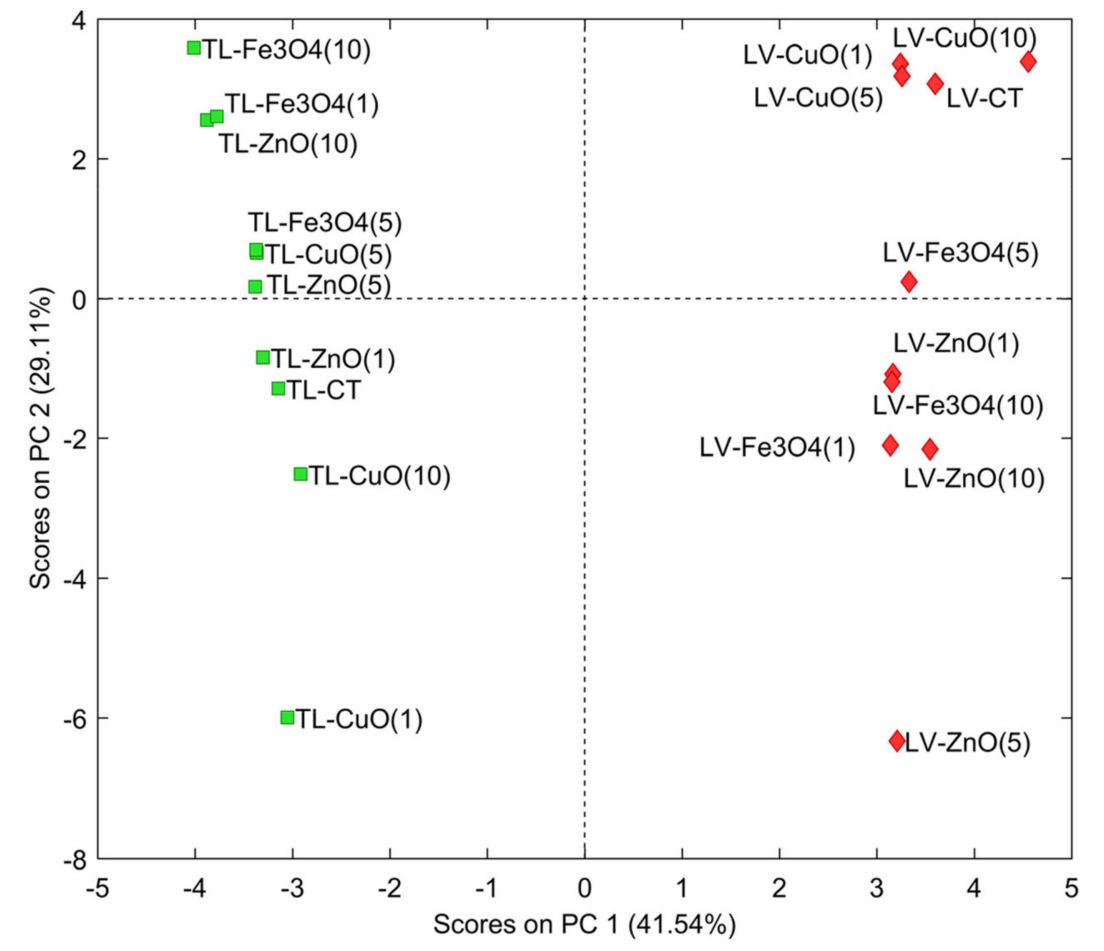

B

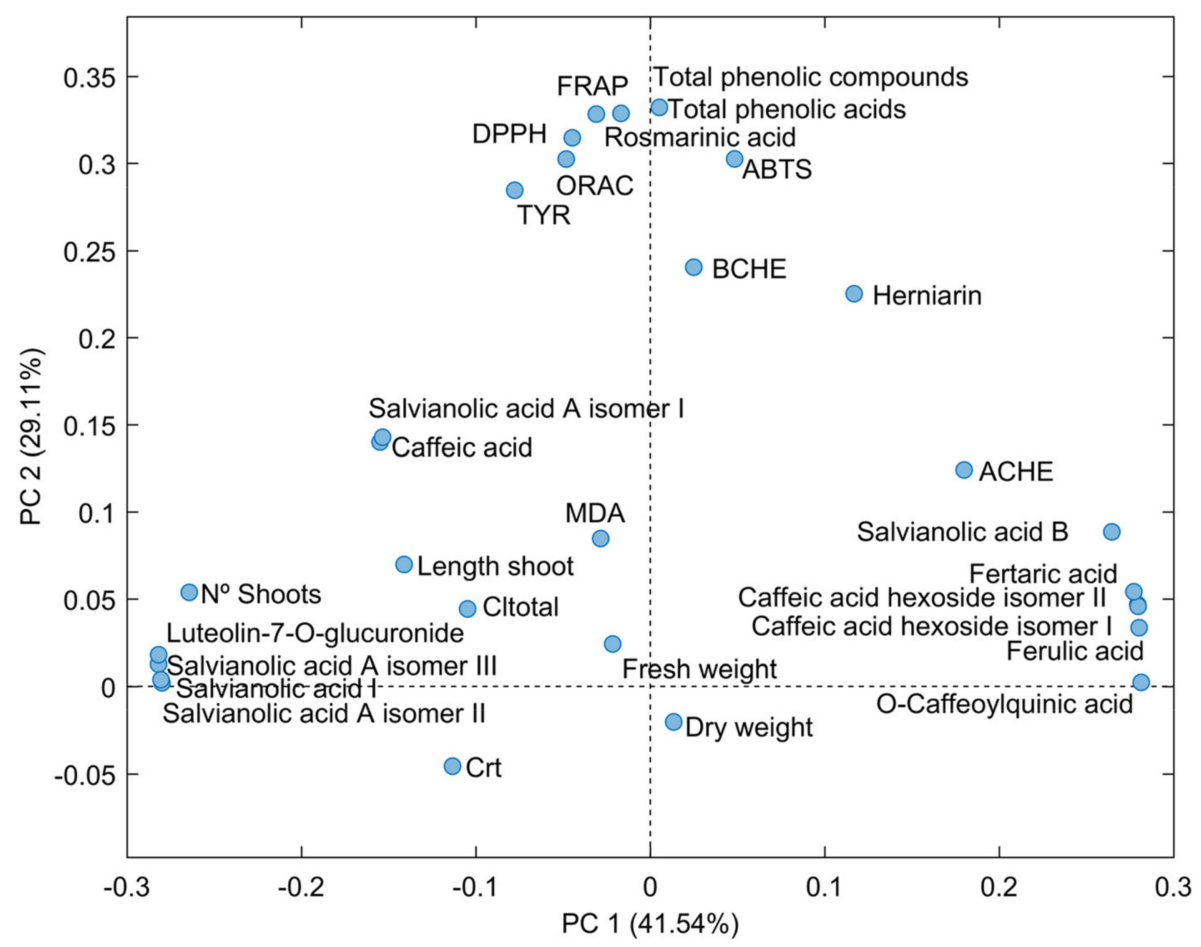

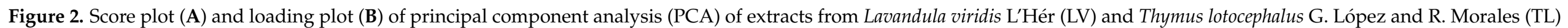
shoots cultured in media with 0 (control), 1, 5 or $10 \mathrm{mg} / \mathrm{mL}$ of $\mathrm{CuO}, \mathrm{ZnO}$ and $\mathrm{Fe}_{3} \mathrm{O}_{4}$ nanoparticles. 


\section{Materials and Methods}

\subsection{Chemicals and Reagents}

2,2'-Azino-bis (3-ethylbenzothiazoline-6-sulfonic acid) diammonium salt (ABTS) tablets, potassium persulfate $\left(\mathrm{K}_{2} \mathrm{~S}_{2} \mathrm{O}_{8}\right)$, DPPH, 6-benzyladenine (BA), methanol, trichloroacetic acid (TCA), 2-thiobarbituric acid (TBA), 5,5'-dithiobis(2-nitrobenzoic acid) (DTNB), 3,4dihydroxy-L-phenylalanine (L-DOPA), acetylthiocholine iodide, S-butyrylthiocholine iodide, galantamine, AChE from Electrophorus electricus (electric eel, EC 3.1.1.7, Type VIS), $\mathrm{BChE}$ from equine serum horse-serum (EC 3.1.1.8), tyrosinase (EC 1.14.18.1) from mushroom, kojic acid, $\mathrm{CuO}$ nanopowder ( $<50 \mathrm{~nm}$ particle size), $\mathrm{ZnO}$ dispersion NPs $(<100 \mathrm{~nm}$ particle size, $\leq 40 \mathrm{~nm}$ average particle size), and $\mathrm{Fe}_{3} \mathrm{O}_{4}$ nanopowder (50-100 nm particle size) were purchased from Sigma-Aldrich (Steinheim, Germany). ( \pm )-6-Hydroxy-2,5,7,8tetramethylchromane-2-carboxylic acid (Trolox), AAPH and fluorescein were supplied from Acros Organics (Geel, Belgium). Ascorbic acid was acquired from Merck (Darmstadt, Germany). Pure acetone was purchased from José Manuel Gomes dos Santos, Lda (Odivelas, Portugal) and Agar from Duchefa Biochemie B.V. (Haarlem, The Netherlands). Ferulic acid, caffeic acid and apigenin were obtained from AASC Ltd. (Southhampton, UK), and rosmarinic acid was acquired from Extrasynthese (Genay, France).

\subsection{Plant Material, Treatments and Culture Conditions}

In vitro shoot-cultures of $L$. viridis and T. lotocephalus multiplied in half strength MS medium (Murashige and Skoog 1962) with $0.2 \mathrm{mg} / \mathrm{L}$ 6-benzyladenine (BA) [22] and in MS medium [23], respectively, were used as plant material in the assays.

To evaluate the effect of NPs, 1,5 or $10 \mathrm{mg} / \mathrm{L}$ of commercial $\mathrm{CuO}, \mathrm{ZnO}$ or $\mathrm{Fe}_{3} \mathrm{O}_{4} \mathrm{NPs}$ were added to the mentioned multiplication medium of each species. NPs were dissolved directly in distilled water, dispersed by an ultrasonic bath (Elma Hans Schmidbauer GmbH and Co. KG, Singen, Germany) for $40 \mathrm{~min}$, and added at an appropriate amount to the culture medium before autoclaving. Medium with no NPs was used as control treatment. All media contained $2 \%(w / v)$ sucrose and $0.7 \%(w / v)$ agar and were autoclaved at $121{ }^{\circ} \mathrm{C}$ for $20 \mathrm{~min}$. Shoots were cultivated in Erlenmeyer flasks containing $80 \mathrm{~mL}$ of agar-solidified medium. Cultures were incubated at $25 \pm 2{ }^{\circ} \mathrm{C}$ with a 16-h photoperiod (cool white fluorescent lamps, $40 \mu \mathrm{mol} \mathrm{m}{ }^{-2} \mathrm{~s}^{-1}$ ) and subcultured every 6 weeks. For each treatment 12 Erlenmeyer flasks with 7 shoots each were tested.

\subsection{Biometric Features}

After 6 weeks of treatment, the total number of shoots produced per culture, the length of the longest shoot and the fresh and dry weight of the biomass produced were recorded. Fresh and dry weight measurements were determined in all shoots produced per Erlenmeyer flask. Plant material was oven-dried $\left(\right.$ at $63^{\circ} \mathrm{C}$ ) until they reached a constant weight for the determination of dry weight.

\subsection{Photosynthetic Pigments Analysis}

Photosynthetic pigments were extracted from fresh plant material $(25 \mathrm{mg})$ using $100 \%$ acetone $(4 \mathrm{~mL})$. The absorbance of the extract solutions was measured in a spectrophotometer at 661.6, 644.8 and $470 \mathrm{~nm}$. Pigment contents were estimated as described by Lichtenthaler [59] using the equatuons below:

$$
\begin{gathered}
\text { Cla }(\mu \mathrm{g} / \mathrm{mL})=11.24 \times \mathrm{Abs}_{661.6}-2.04 \times \mathrm{Abs}_{644.8} \\
\mathrm{Clb}(\mu \mathrm{g} / \mathrm{mL})=20.13 \times \mathrm{Abs}_{644.8}-4.19 \times \mathrm{Abs}_{661.6} \\
\operatorname{Cltotal}(\mu \mathrm{g} / \mathrm{mL})=7.05 \times \mathrm{Abs}_{661.6}+18.09 \times \mathrm{Abs}_{644.8} \\
\operatorname{Crt}(\mu \mathrm{g} / \mathrm{mL})=\left(1000 \times \mathrm{Abs}_{470}-1.90 \times \mathrm{Cla}-63.14 \times \mathrm{Clb}\right) / 214
\end{gathered}
$$




\subsection{Determination of Lipid Peroxidation}

The quantification of malondialdehyde (MDA) content was used as an estimation of lipid peroxidation according to the method described by Hodges et al. [60]. Fresh plant material $(100 \mathrm{mg})$ was crushed in a TCA solution $(0.1 \%, w / v)$ and centrifuged at $10,000 \times g$ for $5 \mathrm{~min}$. The supernatant obtained was added to either $20 \%(w / v)$ TCA (-TBA solution) or $0.5 \%(w / v)$ TBA in $20 \%(w / v)$ TCA (+TBA solution). These mixtures were incubated at $95^{\circ} \mathrm{C}$ for $30 \mathrm{~min}$ and then cooled in an ice bath. After centrifugation $(3000 \times g$ for $10 \mathrm{~min})$ the absorbance of the supernatant was measured at 532, 600 and $440 \mathrm{~nm}$ and the MDA equivalents were calculated using the equations below [60]:

$$
\begin{gathered}
\text { Equivalents } \mathrm{MDA}(\mathrm{nmol} / \mathrm{mL})=(\mathrm{A}-\mathrm{B}) / 157,000 \times 10^{6} \\
\mathrm{~A}=\left(\mathrm{Abs}_{532+\mathrm{TBA}}-\mathrm{Abs}_{600+\mathrm{TBA}}\right)-\left(\mathrm{Abs}_{532-\mathrm{TBA}}-\mathrm{Abs}_{600-\mathrm{TBA}}\right) \\
\mathrm{B}=\left(\mathrm{Abs}_{440+\mathrm{TBA}}-\mathrm{Abs}_{600+\mathrm{TBA}}\right) \times 0.0571
\end{gathered}
$$

\subsection{Extraction of Phenolics}

The regenerated shoots were dried $\left(40^{\circ} \mathrm{C}\right)$ until constant weight and powdered ( $<2 \mathrm{~mm}$ particle size). The plant material was extracted with methanol (500 $\mathrm{mg}$ shoot material/30 mL solvent) for $30 \mathrm{~min}$ in an ultrasound water bath (Elma Hans Schmidbauer $\mathrm{GmbH}$ and Co. KG, Singen, Germany) at room temperature. The obtained extracts were filtered, the solvent was evaporated in a rotary evaporator under reduced pressure $\left(40{ }^{\circ} \mathrm{C}\right)$, and stored at $-20^{\circ} \mathrm{C}$ until use.

\subsection{HPLC-HR-MS Analysis of Phenolic Compounds}

The phenolic compounds profile of plant extracts (1:100) was analysed using a Dionex Ultimate 3000 HPLC system comprising of a HPLC pump and an autosampler operating at $4{ }^{\circ} \mathrm{C}$ (Thermo Scientific, San Jose, CA, USA). Briefly, the separation of compounds was carried out with a $150 \times 4.6 \mathrm{~mm}$ i.d. $5 \mu \mathrm{m} 100$ A C18 Kinetex column (Phenomenex, Macclesfield, UK). The injection volume was $5 \mu \mathrm{L}$ and the separation was obtained at a flow rate of $1 \mathrm{~mL} / \mathrm{min}$ maintained at $40{ }^{\circ} \mathrm{C}$. The chromatographic conditions were carried out following those used by Mansinhos et al. [43]. After the PDA detector, part of the column eluate went $(0.2 \mathrm{~mL} / \mathrm{min})$ directly to an Exactive Orbitrap mass spectrometer (Thermo Fisher Scientific, San José, CA, USA) fitted with a heated electrospray ionization probe (HESI) operating in negative ionization mode. Full scans were recorded in $m / z$ range from 100 to 1000 with a resolution of $50,000 \mathrm{~Hz}$ and with a full automatic gain control (AGC) target of 1,000,000 charges, using 2 microscans. The analyses were also based on scans with in-source collision-induced dissociation (CID) at $25 \mathrm{eV}$. The MS experimental conditions with HESI in negative ionization mode were: capillary temperature of $320^{\circ} \mathrm{C}$, heater temperature of $150^{\circ} \mathrm{C}$, the sheath gas was 25 units, the auxiliary gas was 5 units, and the spray voltage was $4 \mathrm{kV}$.

Data acquisition and processing were carried out using Xcalibur software (Thermo Fisher Scientific, CA, USA). The Exactive Orbitrap was externally calibrated weekly using ready-to-use calibration mixtures (Pierce ESI Negative Ion Calibration Solution and Pierce LQT ESI Positive Ion Calibration Solution, both available from Thermo Fisher Scientific, San José, CA, USA). Quality control (QC) samples were applied to assess and verify the analytical process. The QC samples, composed of identical aliquots of a representative pool of the plant extracts, were injected regularly throughout the run. This QC sample represented both the sample matrix and metabolite composition of the samples and was used to monitor drifts and to determine the variance of a metabolite feature (below 20\%).

Tentative identification of phenolic compounds (Table S1 was achieved as follows: (a) by comparing the exact mass and the retention time (RT) with the available standards and (b) in the absence of standards, compounds were tentatively identified by comparing the theoretical exact mass of the molecular ion with the measured accurate mass of the molecular ion and searched against Metlin, Phenol Explorer, PubChem and ChemSpider 
metabolite databases. In addition, these compounds were previously identified in plants of the same genus $[8,14,44,61]$. Metabolites having molecular masses within the pre-specified tolerance (mass difference less than $5 \mathrm{ppm}$ ) of the query masses are retrieved from these databases. Additionally, the identification of compounds was carried out following the MSI MS levels previously established by Sumner et al. [62], in which the metabolites identified using $m / z$, RT and/or MS/MS of reference standards were classified in level 1 and putatively annotated compounds using $m / z$, RT and/or MS/MS from the spectral library and no reference standards were labelled in level 2. The characteristics such as exact mass, delta ppm between experimental, retention time and MSI MI level are summarized in Supplementary Table S1. Phenolic compounds were quantified using the areas of their chromatographic peaks by selecting the theoretical exact mass of the molecular ion by reference to standard curves. In absence of reference compounds, they were quantified by reference to the calibration curve of a closely related parent compound (based on their structures). The linearity was determined for all the available standards. Limits of detection (LOD) and limits of quantification (LOQ) were estimated from the standard deviation of ten determinations of a blank. LOD and LOQ ranged from 0.00 to $0.50 \mathrm{mg} / \mathrm{L}$ and 0.01 to $1.68 \mathrm{mg} / \mathrm{L}$, respectively. The different parameters used in the quantification of phenolic compounds are summarized in Supplementary Table S2. All the analyses were performed in triplicate.

\subsection{Antioxidant Activity}

The antioxidant activity results were expressed in equivalents of standard compounds calculated using the regression equations of standard plots obtained in each method.

\subsubsection{ABTS Free Radical Scavenging Assay}

A stock solution of $\mathrm{ABTS}^{\bullet+}$, prepared using potassium persulfate as the oxidizing agent, was diluted to give an absorbance of 0.700 at $734 \mathrm{~nm}$ [63]. The absorbance of $190 \mu \mathrm{L}$ of this solution with $10 \mu \mathrm{L}$ of the plant extract was measured at $734 \mathrm{~nm}$. The extract dilution that produced $20-80 \%$ inhibition of the blank absorbance (inhibition $(\%)=(1-$ $\left.\mathrm{Abs}_{\text {extract }} / \mathrm{A}_{\text {blank }}\right) \times 100$ ) was used to calculate the results that were expressed as milligrams of Trolox equivalents per gram of extract $\left(\mathrm{mg}_{\mathrm{TE}} / \mathrm{g}_{\text {extract }}\right)$.

\subsubsection{DPPH Free Radical Scavenging Assay}

This assay was performed according to the method described by Soler-Rivas et al. [64] with some modifications. A mixture containing $30 \mu \mathrm{L}$ of plant extract, $300 \mu \mathrm{L}$ of a $90 \mu \mathrm{M}$ DPPH methanolic solution and $570 \mu \mathrm{L}$ of methanol was incubated at room temperature for $30 \mathrm{~min}$ before reading the absorbance at $515 \mathrm{~nm}$. The extract dilution that produced $20-80 \%$ inhibition of the blank absorbance was used to calculate the results that were expressed as milligrams of Trolox equivalents (TE) per gram of extract $\left(\mathrm{mg}_{\mathrm{TE}} / \mathrm{g}_{\text {extract }}\right)$.

\subsubsection{Ferric Reducing Antioxidant Power (FRAP)}

The reducing properties of the extracts were determined according to the method described by Pulido et al. [65]. For that, a mixture containing $100 \mu \mathrm{L}$ of plant extract, $250 \mu \mathrm{L}$ of sodium phosphate buffer $(200 \mathrm{mM}, \mathrm{pH} 6.6)$ and $250 \mu \mathrm{L}$ of $1 \% \mathrm{~K}_{3}\left[\mathrm{Fe}(\mathrm{CN})_{6}\right]$ was incubated at $50{ }^{\circ} \mathrm{C}(20 \mathrm{~min})$. Then, $250 \mu \mathrm{L}$ of $10 \%$ TCA were added to this mixture that was centrifuged. The obtained supernatant was mixed with the same amount of water $(100 \mu \mathrm{L})$ and $20 \mu \mathrm{L}$ of a $\mathrm{FeCl}_{3}$ solution $(0.1 \%)$ and the absorbance was measured at $700 \mathrm{~nm}$. The results were expressed as milligrams of ascorbic acid equivalents per gram of extract $\left(\mathrm{mg}_{\mathrm{AAE}} / \mathrm{g}_{\text {extract }}\right)$.

\subsubsection{Oxygen Radical Absorbance Capacity (ORAC) Assay}

The ORAC assay was conducted using AAPH as a peroxyl radical generator [66]. A mixture containing $150 \mu \mathrm{L}$ of $0.2 \mu \mathrm{M}$ fluorescein solution (fluorescent probe) and $25 \mu \mathrm{L}$ of plant extract was incubated at $37^{\circ} \mathrm{C}$ in microplates. After $10 \mathrm{~min}$ of the incubation period, 
$25 \mu \mathrm{L}$ of $150 \mathrm{mM}$ AAPH solution were added to each well and the reduction in fluorescence was measured by reading fluorescein excitation at $485 \mathrm{~nm}$ and emission at $530 \mathrm{~nm}$ for $90 \mathrm{~min}$. The ORAC values were calculated using the quadratic regression equation obtained from concentrations of Trolox stock solutions and the area under the curve (AUC). Results were expressed as milligrams of TE per gram of extract $\left(\mathrm{mg}_{\mathrm{TE}} / \mathrm{g}_{\text {extract }}\right)$.

\subsection{Enzyme Inhibitory Capacity}

\subsubsection{Tyrosinase}

Tyrosinase activity was measured according to the method described by Masuda et al. [67]. Sodium phosphate buffer $(20 \mathrm{mM}, \mathrm{pH} 6.8)(80 \mu \mathrm{L})$ was mixed with a $46 \mathrm{U} / \mathrm{mL}$ tyrosinase solution prepared in buffer $(40 \mu \mathrm{L})$ and the plant extract $(40 \mu \mathrm{L})$. After incubation at room temperature for $10 \mathrm{~min} 40 \mu \mathrm{L}$ of L-3,4-dihydroxyphenylalanine (L-DOPA, substrate) were added and after another incubation period of $10 \mathrm{~min}$ the absorbance of the mixture was measured at $475 \mathrm{~nm}$. A blank sample without enzyme was also performed to eliminate some interference of the extract colour. The inhibition percentages were calculated against a blank without extract and the results were expressed as milligrams of kojic acid equivalents per gram of extract calculated using the regression equation of a standard plot $\left(\mathrm{mg}_{\mathrm{KAE}} / \mathrm{g}_{\text {extract }}\right)$.

\subsubsection{Cholinesterases}

The evaluation of AChE and BChE inhibitory activity was based on Ellman's method [68], using a 96-well microplate reader. Initially, $125 \mu \mathrm{L}$ of $3 \mathrm{mM}$ DTNB solution, $25 \mu \mathrm{L}$ of $15 \mathrm{mM}$ substrate solution (acetylthiocholine iodide or S-butyrylthiocholine), $50 \mu \mathrm{L}$ of $100 \mathrm{mM}$ phosphate buffer ( $\mathrm{pH} 8.0$ ) and $25 \mu \mathrm{L}$ of plant extract were mixed. Then, $25 \mu \mathrm{L}$ of enzyme solution $(0.28 \mathrm{U} / \mathrm{mL})$ were added to the mixture and the absorbance was read at $405 \mathrm{~nm}$. The inhibition percentages were calculated against a blank without extract and the results were expressed as milligrams of galantamine equivalents per gram of extract calculated using the regression equation of a standard plot $\left(\mathrm{mg}_{\mathrm{GE}} / \mathrm{g}_{\text {extract }}\right)$.

\subsection{Statistical Analysis}

The data were presented as the means \pm standard errors of three replicates of each experiment. Data were analyzed by one-way analysis of variance (ANOVA), and Duncan's New Multiple Range Test $(p<0.05)$, and correlations were calculated using Pearson's test. Statistical analyses were carried out using IBM SPSS Statistics for Windows, Version 25.0. Armonk, NY: IBM Corp. Data were auto-scaled and a principal component analysis (PCA) was performed using the statistical software SOLO v. 8.6 (Eigenvector Research Inc., Manson, WA, USA).

\section{Conclusions}

Our results suggest that NPs added to culture media have a significant impact on different parameters of $L$. viridis and T. lotocephalus in vitro shoot cultures. The results varied with the species but also with the NP treatment. In T. lotocephalus $\mathrm{ZnO}$ and $\mathrm{Fe}_{3} \mathrm{O}_{4}$ have a positive effect on phenolics production and antioxidant activity suggesting that NPs can be useful as chemical elicitors in this species. However, in L. viridis only CuO NPs at $10 \mathrm{mg} / \mathrm{L}$ slightly improved the chemical contents and biological activities, suggesting that other types of NPs should be tested to induce a higher production of bioactive compounds in this species. Although this research opens new avenues for studying different nanoelicitors for the exploration of in vitro culture as a beneficial biotechnological strategy for the production of plant bioactivities, more detailed work is required using NPs adequately characterized. 
Supplementary Materials: The following are available online. Table S1: HPLC-HR-MS data of identified phenolic compounds from Lavandula viridis L'Hér and Thymus lotocephalus G. Lopez and R. Morales extracts, Table S2: Summary of HPLC-HR-MS parameters for quantification of phenolic compounds in Lavandula viridis L'Hér and Thymus lotocephalus G. Lopez and R. Morales extracts.

Author Contributions: Conceptualization, I.M., S.G. and A.R.; methodology, I.M., S.G. and R.R.-S.; software, S.G., I.M. and R.R.-S.; validation, I.M., S.G., R.R.-S., G.P.-C. and A.R.; formal analysis, I.M., S.G. and R.R.-S.; investigation, I.M., S.G., R.R.-S. and A.R.; resources, J.M.M.-R. and A.R.; data curation, S.G., I.M. and R.R.-S.; writing-original draft preparation, S.G., I.M. and R.R.-S.; writingreview and editing, S.G., I.M., R.R.-S., G.P.-C., J.M.M.-R. and A.R.; supervision, S.G. and A.R.; project administration, S.G. and A.R.; funding acquisition, J.M.M.-R. and A.R. All authors have read and agreed to the published version of the manuscript.

Funding: This research was funded by the project INTERREG-MD.NET: When Brand Meets People and by National Funds through FCT-Foundation for Science and Technology under the Project UIDB/05183/2020. Sandra Gonçalves (under the Norma Transitória-DL 57/2016/CP1361/CT0022) and Inês Mansinhos (Grant SFRH/BD/145243/2019) are funded by national funds through FCT. Raquel Rodríguez Solana was supported by a Juan de la Cierva-Incorporation contract from the Spanish Ministry of Science, Innovation and Universities (IJC2018-036207-I).

Institutional Review Board Statement: Not applicable.

Informed Consent Statement: Not applicable.

Conflicts of Interest: The authors declare no conflict of interest.

\section{References}

1. Torre, B.G.; Albericio, F. The pharmaceutical industry in 2018. an analysis of FDA drug approvals from the perspective of molecules. Molecules 2018, 24, 809. [CrossRef]

2. Marchev, A.S.; Yordanova, Z.P.; Georgiev, M.I. Green (cell) factories for advanced production of plant secondary metabolites. Crit. Rev. Biotechnol. 2020, 40, 443-458. [CrossRef]

3. Trivellini, A.; Lucchesini, M.; Maggini, R.; Mosadegh, H.; Villamarin, T.S.S.; Vernieri, P.; Mensuali-Sodi, A.; Pardossi, A. Lamiaceae phenols as multifaceted compounds: Bioactivity, industrialprospects and role of "positive-stress". Ind. Crops Prod. 2016, 83, 241-254. [CrossRef]

4. Tzima, K.; Brunton, N.P.; Rai, D.K. Qualitative and quantitative analysis of polyphenols in Lamiaceae plants-A review. Plants 2018, 7, 25. [CrossRef]

5. Salehi, B.; Mnayer, D.; Özçelik, B.; Altin, G.; Kasapoğlu, K.N.; Daskaya-Dikmen, C.; Sharifi-Rad, M.; Selamoglu, Z.; Acharya, K.; Sen, S.; et al. Plants of the genus Lavandula: From farm to pharmacy. Nat. Prod. Commun. 2018, 13, 1385-1402. [CrossRef]

6. Li, X.; He, T.; Wang, X.; Shen, M.; Yan, X.; Fan, S.; Wang, L.; Wang, X.; Xu, X.; Sui, H.; et al. Traditional uses, chemical constituents and biological activities of plants from the genus Thymus. Chem. Biodiv. 2019, 16, e1900254. [CrossRef] [PubMed]

7. Salehi, B.; Abu-Darwish, M.S.; Tarawneh, A.H.; Cabral, C.; Gadetskaya, A.V.; Salgueiro, L.; Hosseinabadi, T.; Rajabi, S.; Chanda, W.; Sharifi-Rad, M.; et al. Thymus spp. Plants-Food applications and phytopharmacy properties. Trends Food Sci. Technol. 2019, 85, 287-306. [CrossRef]

8. Costa, P.; Gonçalves, S.; Andrade, P.B.; Valentão, P.; Romano, A. Inhibitory effect of Lavandula viridis on Fe ${ }^{2+}$-induced lipid peroxidation, and antioxidant and anti cholinesterase properties. Food Chem. 2011, 126, 1779-1786. [CrossRef] [PubMed]

9. Costa, P.; Gonçalves, S.; Grosso, C.; Andrade, P.B.; Valentão, P.; Bernardo-Gil, M.G.; Romano, A. Chemical profiling and biological screening of Thymus lotocephalus extracts obtained by supercritical fluid extraction and hydrodistillation. Ind. Crops Prod. 2012, 36, 246-256. [CrossRef]

10. Costa, P.; Grosso, C.; Gonçalves, S.; Andrade, P.B.; Valentão, P.; Bernardo-Gil, M.G.; Romano, A. Supercritical fluid extraction and hydrodistillation for the recovery of bioactive compounds from Lavandula viridis L'Hér. Food Chem. 2012, 135, 112-121. [CrossRef]

11. Costa, P.; Gonçalves, S.; Valentão, P.; Andrade, P.B.; Coelho, N.; Romano, A. Thymus lotocephalus wild plants and in vitro cultures produce different profiles of phenolic compounds with antioxidant activity. Food Chem. 2012, 135, 1253-1260. [CrossRef]

12. Costa, P.; Gonçalves, S.; Valentão, P.; Andrade, P.B.; Romano, A. Accumulation of phenolic compounds in in vitro cultures and wild plants of Lavandula viridis L'Hér and their antioxidant and anticholinesterase potential. Food Chem. Toxicol. 2013, 57, 69-74. [CrossRef]

13. Costa, P.; Sarmento, B.; Gonçalves, S.; Romano, A. Protective effects of Lavandula viridis L'Hér extracts and rosmarinic acid against $\mathrm{H}_{2} \mathrm{O}_{2}$-induced oxidative damage in A172 human astrocyte cell line. Ind. Crops Prod. 2013, 50, 361-365. [CrossRef]

14. Gonçalves, S.; Mansinhos, I.; Rodríguez-Solana, R.; Pérez-Santín, E.; Coelho, N.; Romano, A. Elicitation improves rosmarinic acid content and antioxidant activity in Thymus lotocephalus shoot cultures. Ind. Crops Prod. 2019, 137, 214-220. [CrossRef]

15. Espinosa-Leal, C.A.; Puente-Garza, C.A.; García-Lara, S. In vitro plant tissue culture: Means for production of biological active compounds. Planta 2018, 248, 1-18. [CrossRef] [PubMed] 
16. Gonçalves, S.; Romano, A. In vitro culture of lavenders (Lavandula spp.) and the production of secondary metabolites. Biotechnol. Adv. 2013, 31, 166-174. [CrossRef]

17. Gonçalves, S.; Romano, A. Production of plant secondary metabolites by using biotechnological tools. In Secondary Metabolites: Sources and Applications; Vijayakumar, R., Raja, S.S.S., Eds.; InTech: Rijeka, Croatia, 2018.

18. Yadav, V. Nanotechnology, big things from a tiny world: A review. Int. J. Serv. Sci. Technol. 2013, 3, 771-778.

19. Kim, D.H.; Gopal, J.; Sivanesan, I. Nanomaterials in plant tissue culture: The disclosed and undisclosed. RSC Adv. 2017, 7 , 36492-36505. [CrossRef]

20. Marslin, G.; Sheeba, C.J.; Franklin, G. Nanoparticles alter secondary metabolism in plants via ROS burst. Front. Plant Sci. 2017, 8, 832. [CrossRef] [PubMed]

21. Isah, T.; Umar, S.; Mujib, A.; Sharma, M.P.; Rajasekharan, P.E.; Zafar, N.; Frukh, A. Secondary metabolism of pharmaceuticals in the plant in vitro cultures: Strategies, approaches, and limitations to achieving higher yield. Plant Cell Tissue Organ. Cult. 2018, 132, 239-265. [CrossRef]

22. Dias, M.C.; Almeida, R.; Romano, A. Rapid clonal multiplication of Lavandula viridis L'Hér through in vitro axillary shoot proliferation. Plant Cell Tissue Organ. Cult. 2002, 68, 99-102. [CrossRef]

23. Coelho, N.; Gonçalves, S.; González-Benito, M.E.; Romano, A. Establishment of an in vitro propagation protocol for Thymus lotocephalus, a rare aromatic species of the Algarve (Portugal). Plant Growth Regul. 2012, 66, 69-74. [CrossRef]

24. Baskar, V.; Safia, N.; Preethy, K.S.; Dhivya, S.; Thiruvengadam, M.; Sathishkumar, R. A comparative study of phytotoxic effects of metal oxide ( $\mathrm{CuO}, \mathrm{ZnO}$ and $\mathrm{NiO})$ nanoparticles on in-vitro grown Abelmoschus esculentus. Plant Biosyst. 2020, 155, 374-383. [CrossRef]

25. El-Mahdy, M.T.; Elazab, D.S. Impact of zinc oxide nanoparticles on pomegranate growth under in vitro conditions. Russ. J. Plant Physiol. 2020, 67, 162-167. [CrossRef]

26. Al-Mayahi, A.M.W. The effect of humic acid (HA) and zinc oxide nanoparticles (ZnO-NPS) on in vitro regeneration of date palm (Phoenix dactylifera L.) cv. Quntar. Plant Cell Tissue Organ. Cult. 2021, 145, 445-456. [CrossRef]

27. Thunugunta, T.; Reddy, A.C.; Seetharamaiah, S.K.; Hunashikatti, L.R.; Chandrappa, S.G.; Kalathil, N.C.; Reddy, L.R.D.C. Impact of Zinc oxide nanoparticles on eggplant (S. melongena): Studies on growth and the accumulation of nanoparticles. IET Nanobiotechnol. 2018, 12, 706-713. [CrossRef]

28. Da Costa, M.; Sharma, P. Effect of copper oxide nanoparticles on growth, morphology, photosynthesis, and antioxidant response in Oryza sativa. Photosynthetica 2016, 54, 110-119. [CrossRef]

29. Javed, R.; Zia, M.; Yücesan, B.; Gürel, E. Abiotic stress of ZnO-PEG, ZnO-PVP, CuO-PEG and CuO-PVP nanoparticles enhance growth, sweetener compounds and antioxidant activities in shoots of Stevia rebaudiana Bertoni. IET Nanobiotechnol. 2017, 11, 898-902. [CrossRef]

30. George, E.F.; Hall, M.A.; De Klerk, G.-J. The components of plant tissue culture media I: Macro-and micro-nutrients. In Plant Propagation by Tissue Culture, 3rd ed.; Springer: Dordrecht, The Netherlands, 2008; pp. 65-113.

31. Mozafari, A.A.; Havas, F.; Ghaderi, N. Application of iron nanoparticles and salicylic acid in in vitro culture of strawberries (Fragaria $\times$ ananassa Duch.) to cope with drought stress. Plant Cell Tissue Organ. Cult. 2018, 132, 511-523. [CrossRef]

32. Ngan, H.T.M.; Tung, H.T.; Lea, B.V.; Nhut, D.T. Evaluation of root growth, antioxidant enzyme activity and mineral absorbability of carnation (Dianthus caryophyllus "Express golem") plantlets cultured in two culture systems supplemented with iron nanoparticles. Sci. Hortic. 2020, 272, 109612. [CrossRef]

33. Liu, X.M.; Zhang, F.D.; Feng, Z.B.; Zang, S.Q.; He, X.S.; Wang, R.F.; Wang, Y.J. Effects of nano-ferric oxide on the growth and nutrients absorption of peanut. Plant Nutr. Fertil. Sci. 2005, 11, 551-555.

34. Joseph, S.; Anawar, H.M.; Storer, P.; Blackwell, P.; Chia, C.; Lin, Y.; Munroe, P.; Donne, S.; Horvat, J.; Wang, J.; et al. Effects of enriched biochars containing magnetic iron nanoparticles on mycorrhizal colonization, plant growth, nutrient uptake and soil quality improvement. Pedosphere 2015, 25, 749-760. [CrossRef]

35. Jadczak, P.; Kulpa, D.; Bihun, M.; Przewodowski, W. Positive effect of AgNPs and AuNPs in in vitro cultures of Lavandula angustifolia Mill. Plant Cell Tissue Organ. Cult. 2019, 139, 191-197. [CrossRef]

36. Jiang, H.M.; Yang, J.C.; Zhang, J.F. Effects of external phosphorus on the cell ultrastructure and the chlorophyll content of maize under cadmium and zinc stress. Environ. Pollut. 2007, 147, 750-756. [CrossRef]

37. Ebbs, S.; Uchil, S. Cadmium and zinc induced chlorosis in Indian mustard [Brassica juncea (L.) Czern] involves preferential loss of chlorophyll b. Photosynthetica 2008, 46, 49-55. [CrossRef]

38. Abdel-Wahab, D.A.; Othman, N.A.R.M.; Hamada, A.M. Effects of copper oxide nanoparticles to Solanum nigrum and its potential for phytoremediation. Plant Cell Tissue Organ. Cult. 2019, 137, 525-539. [CrossRef]

39. Chang, Y.N.; Zhang, M.; Xia, L.; Zhang, J.; Xing, G. The toxic effects and mechanisms of CuO and ZnO nanoparticles. Materials 2012, 5, 2850-2871. [CrossRef]

40. García-Gómez, C.; Obrador, A.; González, D.; Babín, M.; Fernández, M.D. Comparative effect of ZnO NPs, ZnO bulk and ZnSO 4 in the antioxidant defences of two plant species growing in two agricultural soils under greenhouse conditions. Sci. Total Environ. 2017, 589, 11-24. [CrossRef]

41. Hawrył, A.; Hawrył, M.; Waksmundzka-Hajnos, M. Liquid chromatography fingerprint analysis and antioxidant activity of selected lavender species with chemometric calculations. PLoS ONE 2020, 14, e0218974. [CrossRef] 
42. Lopes, C.L.; Pereira, E.; Soković, M.; Carvalho, A.M.; Barata, A.M.; Lopes, V.; Rocha, F.; Calhelha, R.C.; Barros, L.; Ferreira, I.C.F.R. Phenolic composition and bioactivity of Lavandula pedunculata (Mill.) Cav. samples from different geographical origin. Molecules 2018, 23, 1037. [CrossRef] [PubMed]

43. Mansinhos, I.; Gonçalves, S.; Rodríguez-Solana, R.; Ordóñez-Díaz, J.L.; Moreno-Rojas, J.M.; Romano, A. Ultrasonic-Assisted extraction and natural deep eutectic solvents combination: A Green strategy to improve the recovery of phenolic compounds from Lavandula pedunculata subsp. lusitanica (Chaytor) Franco. Antioxidants 2021, 10, 582. [CrossRef]

44. Taghouti, M.; Martins-Gomes, C.; Félix, L.M.; Schäfer, J.; Santos, J.A.; Bunzel, M.; Nunes, F.M.; Silva, A.M. Polyphenol composition and biological activity of Thymus citriodorus and Thymus vulgaris: Comparison with endemic Iberian Thymus species. Food Chem. 2020, 331, 127362. [CrossRef]

45. Silva, A.M.; Martins-Gomes, C.; Souto, E.B.; Schäfer, J.; Santos, J.A.; Bunzel, M.; Nunes, F.M. Thymus zygis subsp. zygis an endemic portuguese plant: Phytochemical profiling, antioxidant, anti-proliferative and anti-inflammatory activities. Antioxidants 2020, 9 , 482. [CrossRef] [PubMed]

46. Sarfaraz, D.; Rahimmalek, M.; Saeidi, G. Polyphenolic and molecular variation in Thymus species using HPLC and SRAP analyses. Sci. Rep. 2021, 11, 5019. [CrossRef] [PubMed]

47. Javed, R.; Yucesan, B.; Zia, M.; Gurel, E. Elicitation of secondary metabolites in callus cultures of Stevia rebaudiana Bertoni grown under $\mathrm{ZnO}$ and $\mathrm{CuO}$ nanoparticles stress. Sugar Tech 2018, 20, 194-201. [CrossRef]

48. Zafar, H.; Attarad, A.; Joham, S.A.; Haq, I.U.; Zia, M. Effect of ZnO nanoparticles on Brassica nigra seedlings and stem explants: Growth dynamics and antioxidative response. Front. Plant Sic. 2016, 7, 535. [CrossRef] [PubMed]

49. Mosavat, N.; Golkar, P.; Yousefifard, M.; Javed, R. Modulation of callus growth and secondary metabolites in different Thymus species and Zataria multiflora micropropagated under ZnO nanoparticles stress. Biotechnol. Appl. Biochem. 2019, 66, 316-322. [CrossRef]

50. Taghizadeh, M.; Nasibi, F.; Kalantari, K.M.; Ghanati, F. Evaluation of secondary metabolites and antioxidant activity in Dracocephalum polychaetum Bornm. cell suspension culture under magnetite nanoparticles and static magnetic field elicitation. Plant Cell Tissue Organ. Cult. 2019, 136, 489-498. [CrossRef]

51. Ahmad, M.A.; Javed, R.; Adeel, M.; Rizwan, M.; Ao, Q.; Yang, Y. Engineered ZnO and CuO nanoparticles ameliorate morphological and biochemical response in tissue culture regenerants of candyleaf (Stevia rebaudiana). Molecules 2020, $25,1356$. [CrossRef]

52. Javed, R.; Usman, M.; Yücesan, B.; Zia, M.; Gürel, E. Effect of zinc oxide (ZnO) nanoparticles on physiology and steviol glycosides production in micropropagated shoots of Stevia rebaudiana Bertoni. Plant Physiol. Biochem. 2017, 110, 94-99. [CrossRef] [PubMed]

53. Moharrami, F.; Hosseini, B.; Sharafi, A.; Farjaminezhad, M. Enhanced production of hyoscyamine and scopolamine from genetically trans-formed root culture of Hyoscyamus reticulatus L. elicited by iron oxide nanoparticles. Vitr. Cell Dev. Biol. Plant 2017, 53, 104-111. [CrossRef] [PubMed]

54. Hussain, M.; Raja, N.I.; Mashwani, Z.; Iqbal, M.; Sabir, S.; Yasmeen, F. In vitro seed germination and biochemical profiling of Artemisia absinthium exposed to various metallic nanoparticles. 3 Biotech 2018, 130, 408-417. [CrossRef]

55. Hsu, C.-K.; Chang, C.-T.; Lu, H.-Y.; Chung, Y.-C. Inhibitory effects of the water extracts of Lavendula sp. on mushroom tyrosinase activity. Food Chem. 2007, 105, 1099-1105. [CrossRef]

56. Mukherjee, P.K.; Biswas, R.; Sharma, A.; Banerjee, S.; Biswas, S.; Katiyar, C.K. Validation of medicinal herbs for anti-tyrosinase potential. J. Herb. Med. 2018, 14, 1-16. [CrossRef]

57. Kang, H.-S.; Kim, H.-R.; Byun, D.-S.; Park, H.-J.; Choi, J.-S. Rosmarinic acid as a tyrosinase inhibitors from Salvia Miltiorrhiza. Nat. Prod. Sci. 2004, 10, 80-84.

58. Karioti, A.; Protopappa, A.; Megoulas, N.; Skaltsa, H. Identification of tyrosinase inhibitors from Marrubium Velutinum and Marrubium Cylleneum. Bioorg. Med. Chem. 2007, 15, 2708-2714. [CrossRef] [PubMed]

59. Lichtenthaler, H.K. Chlorophylls and carotenoids: Pigments of photosynthetic biomembranes. Methods Enzymol. 1987, 148, 350-382.

60. Hodges, D.M.; Delong, J.M.; Forney, C.F.; Prange, R.K. Improving the thiobarbituric acid-reactive-substances assay for estimating lipid peroxidation in plant tissues containing anthocyanin and other interfering compounds. Planta 1999, 207, 604-611. [CrossRef]

61. Contreras, M.D.M.; Algieri, F.; Rodriguez-Nogales, A.; Gálvez, J.; Segura-Carretero, A. Phytochemical Profiling of AntiInflammatory Lavandula Extracts via RP-HPLC-DAD-QTOF-MS and -MS/MS: Assessment of Their Qualitative and Quantitative Differences. Electrophoresis 2018, 39, 1284-1293. [CrossRef] [PubMed]

62. Sumner, L.W.; Amberg, A.; Barrett, D.; Beale, M.H.; Beger, R.; Daykin, C.A.; Fan, T.W.-M.; Fiehn, O.; Goodacre, R.; Griffin, J.L.; et al. Proposed Minimum Reporting Standards for Chemical Analysis Chemical Analysis Working Group (CAWG) Metabolomics Standards Initiative (MSI). Metabolomics 2007, 3, 211-221. [CrossRef] [PubMed]

63. Re, R.; Pellegrini, N.; Proteggente, A.; Pannala, A.; Yang, M.; Rice-Evans, C. Antioxidant activity applying an improved ABTS radical cation decolorization assay. Free Radic. Biol. Med. 1999, 26, 1231-1237. [CrossRef]

64. Soler-Rivas, C.; Espín, J.C.; Wichers, H.J. An easy and fast test to compare total free radical scavenger capacity of foodstuffs. Phytochem. Anal. 2000, 11, 330-338. [CrossRef]

65. Pulido, R.; Bravo, L.; Saura-Calixto, F. Antioxidant activity of dietary polyphenols as determined by a modified ferric reducing/antioxidant power assay. J. Agric. Food Chem. 2000, 48, 3396-3402. [CrossRef] 
66. Gillespie, K.M.; Chae, J.M.; Ainsworth, E.A. Rapid measurement of total antioxidant capacity in plants. Nat. Protoc. 2007, 2, 867-870. [CrossRef] [PubMed]

67. Masuda, T.; Yamashita, D.; Takeda, Y.; Yonemori, S. Screening for tyrosinase inhibitors among extracts of seashore plants and identification of potent inhibitors from Garcinia subelliptica. Biosci. Biotechnol. Biochem. 2005, 69, 197-201. [CrossRef]

68. Ellman, G.L.; Courtney, K.D.; Andres, V.; Featherstone, R.M. A new and rapid colorimetric determination of acetylcholinesterase activity. Biochem. Pharmacol. 1961, 7, 88-95. [CrossRef] 